Journal of Management

Vol. 47 No. 1, January $202143-75$

DOI: $10.1177 / 0149206320929088$

(1) $\$$ (C) The Author(s) 2020

Article reuse guidelines:

sagepub.com/journals-permissions

\title{
Organizational Adaptation
}

\author{
Andrew Sarta (iD \\ Western University \\ Rodolphe Durand \\ HEC Paris \\ Jean-Philippe Vergne \\ University College London
}

\begin{abstract}
Organizational adaptation is equivocal. On the one hand, the concept is ubiquitous in management research and acts as the glue binding together the central issues of organizational change, performance, and survival. On the other hand, it lurks around in various guises (e.g., "fit," "alignment," "congruence," and "strategic change") studied from multiple theoretical streams (e.g., behavioral, resource based, and institutional) and at different levels of analysis (e.g., organization and industry levels). In a novel approach to reviewing 443 adaptation articles that leverages both computational and hand-coded analysis, we produce an interactive visual of the themes most studied by adaptation scholars. We inductively draw out a definition of adaptation as intentional decision making undertaken by organizational members, leading to observable actions that aim to reduce the distance between an organization and its economic and institutional environments. We then review the literature across three main areas of inquiry and six theoretical perspectives that surfaced from our analysis and identify 11 difficulties that have hampered adaptation research in the past 50 years. Our review suggests ways to address these difficulties to enable future research to develop and cumulate.
\end{abstract}

Keywords: adaptation; fit; congruence; topic modeling; evolution; strategic change; performance

\footnotetext{
Acknowledgments: We are thankful to editor Jorge Walter and the two anonymous reviewers for their invaluable feedback and guidance during the review process. This work was supported by an SSHRC grant (No. 430-20150670) and the Scotiabank Digital Banking Lab at Ivey Business School.

Supplemental material for this article is available with the manuscript on the JOM website.

Corresponding author: Andrew Sarta, Ivey Business School, Western University, 1255 Western Road, London, ON N6G 0N1, Canada.

E-mail: asarta.phd@ivey.ca
} 
Adaptation is, perhaps, one of the most pervasive concepts in organizational theory and strategic management. Indeed, Chakravarthy (1982: 35) describes adaptation as "the primary purpose of strategic management." Dating back to the early 20th century and the emergence of scientific management (Taylor, 1911) and industrial administration (Fayol, 1916, 1949), multiple perspectives have underscored the role of adaptation in explaining organizational success (Aldrich \& Ruef, 2006). Underlying much of the literature is the assumption that managers possess the capacity to assess their environments and capitalize on relevant opportunities to act, be successful, and increase the organizations' survival odds.

Unfortunately, the broad applicability of adaptation has led to the proliferation of imperfect synonyms (e.g., "fit," "alignment," "congruence") that are applied in place of, or alongside, adaptation, blurring the comprehension of the notion. From the 1980s and on, discrepant voices objected to the view of an all-adaptive organizational capacity and brought forth the selective forces of economic environments (Aldrich, 1979; Hannan \& Freeman, 1989; McKelvey, 1982). Complicating matters further, adaptation contains a potent analogy with biology, which does not easily translate to the field of management (Durand, 2006; Hodgson, 2013; Vergne \& Depeyre, 2016). As a result, organizational scholars have used the concept of adaptation inconsistently across research traditions (e.g., behavioral theory, population ecology, neoinstitutionalism) without always being able to push the research agenda beyond analogical reasoning (e.g., much like a living organism, when an organization changes something and survives, it looks "as if" it has adapted to its environment).

Adaptation has been reviewed both in general overviews of the environment-organization interface (Aldrich, 1979; Aldrich \& Ruef, 2006; Durand, 2006) and in specific contexts (Eggers \& Park, 2018). These studies debate how organizational adaptation relates to other concepts while eschewing scrutiny of the concept of adaptation itself, potentially contributing to the ambiguities identified at the outset. To use Kipling's metaphor, they observe one aspect of the elephant without considering the whole animal. A specific review of adaptation can harness the merits of past research, define more precisely the concept of adaptation to make the proverbial elephant whole again, identify existing difficulties in the literature, and delineate solutions to address those difficulties.

To ground our review, we first leverage the approach of Podsakoff, MacKenzie, and Podsakoff (2016) and inductively draw out a definition of organizational adaptation as intentional decision making undertaken by organizational members, leading to observable actions that aim to reduce the distance between an organization and its economic and institutional environments. ${ }^{1}$ A boundary condition for this review is a focus on established organizations as opposed to new ventures, since the latter, by definition, do not yet have a legacy resource base in need of adjustment vis-à-vis external environments.

Our definition distinguishes adaptation from generic strategic change and refocuses adaptation research around a specific type of intentional change aimed at increasing convergence between the organization and (some of) its environment(s). Armed with this definition, we are better equipped to distinguish adaptation from its triggers (e.g., pursuing change, responding to institutional pressure) and consequences (e.g., performance, survival). Ultimately, our review clarifies that not every change is necessarily adaptive and that not every adaptive move necessarily increases organizational performance. As a result, our review guides scholars toward consistent uses of adaptation that can resolve ambiguities and promote new insights for both disciplinary and interdisciplinary research (McMahan \& Evans, 2018). 
Our article follows a three-step approach. First, we identify and unpack the vast literature on adaptation and its related labels (e.g., "fit," "congruence"). To do so, we introduce a combination of computer- and human-centered methods to systematically identify and contrast contributions while minimizing researcher bias. More specifically, our mixed method incorporates both topic modeling and systematic hand-coding of manuscripts. The outcome is a synthesized mapping of adaptation scholarship (443 manuscripts), organized around six theoretical streams (e.g., resource based, evolutionary, sociological perspectives) that tackle four high-level themes: "resources, search, and behavioral change"; "routines, capabilities, and knowledge"; "governance and stakeholder management"; and "competitive and institutional pressures."

Second, we use our mapping to identify the three primary areas of inquiry that adaptation scholars have covered: why organizations pursue adaptation, what internal factors preclude or enable adaptation, and what environmental factors urge adaptation. We then discuss and contrast the contributions of each theoretical stream to these areas of inquiry while emphasizing that the diversity of assumptions underpinning the various streams produces ambiguities and difficulties that we are now better equipped to unpack based on our definition of adaptation.

Finally, we discuss 11 common difficulties uncovered through this structured review that often preclude adaptation scholarship from providing logically consistent accounts of reality or actionable recommendations for managers. By building upon our reconceptualization of adaptation, we offer solutions to address these difficulties that can guide future research at the intersection of organizations and their environments.

\section{Navigating the Literature on Organizational Adaptation}

\section{Defining Organizational Adaptation}

The conceptual roots of adaptation emanate from a natural integration of organizational theory and strategic management, most prominent in the work of Chandler (1962), which layered the ideas of strategic decision making and functional efficiency onto the concept of adaptation. Classical works, such as A Behavioral Theory of the Firm (Cyert \& March, 1963) and Differentiation and Integration in Complex Organizations (Lawrence \& Lorsch, 1967), influenced and explicitly elaborated on the related notions of "adaptation" and "fit." Cyert and March (1963) identified the adaptation of decision rules as a critical element in the learning process, whereby organizations evaluate feedback received from the environment and attempt to reconcile misalignments. Concurrently, Lawrence and Lorsch (1967) elaborated on the strategy-structure relationship by identifying the optimal configurations of differentiation and integration that catalyzed research in structural contingency theory. The appropriate fit between internal structures and external subenvironments facilitated superior performance for organizations (Lawrence \& Lorsch, 1967).

Both seminal works established an association between adaptation and fit as notions describing the interface between organizations and environments. Moreover, MerriamWebster (n.d.) explicitly relates these two terms by defining "adaptation" as the noun form of the verb "adapt," which means "to make fit (as for a new use) often by modification." Yet, nuanced interpretations of what it means to adapt developed over time, with prominent works emphasizing different aspects of fit, fitness, ability, and modification to 
varying degrees (Chakravarthy, 1982; Hrebiniak \& Joyce, 1985; Levinthal, 1997; Miles, Snow, Meyer, \& Coleman, 1978; Starbuck, 1971).

Following Podsakoff et al. (2016) and in order to align around a common definition, we extracted and summarized the core aspects of adaptation from definitions provided in 18 seminal works from the 1940s to the early 2000s. Appendix A (see online supplement) describes the inductive process leading to defining adaptation as intentional decision making undertaken by organizational members, leading to observable actions that aim to reduce the distance between an organization and its economic and institutional environments. More specifically, our definition conceptualizes adaptation as (a) intentional, that is, rooted in organizational members' awareness of their environment, resulting in a choice to react to, anticipate, or ignore changes in the environment; (b) relational, whereby organizations and environments influence one another; (c) conditioned, since environmental characteristics also depend on, and evolve with, other organizations' actions; and (d) convergent, in that organizations seeking to adapt are attempting to move closer to a set of environmental characteristics. Appendix A details how these four attributes make adaptation different from related constructs, such as "fitness" or "strategic change."

Armed with this definition, we conducted an exhaustive search in Web of Science, principled on the advice of Short (2009) in preparing high-quality review papers. We searched for "adapt*" and associated terms "fit*," "congrue*," and "renewal" in the title, abstracts, and keywords of Academy of Management Journal, Academy of Management Review, Strategic Management Journal, Administrative Science Quarterly, Journal of Management, Journal of Management Studies, Organization Science, American Journal of Sociology, and American Sociological Review from 1967 to the present day. ${ }^{2}$ In total, 1,274 manuscripts were retrieved with the initial search parameters.

\section{A Computational and Hand-Coded Mixed-Method Approach to Reviewing}

In order to organize the large number of manuscripts retrieved without imposing human bias on the data set, we leveraged the computational method of topic modeling, which uses probabilistic techniques to examine words frequently co-occurring with one another without the need for dictionaries predefined by the researcher (Hannigan et al., 2019). We processed the 1,274 manuscripts in three stages with the article abstracts collectively representing our initial corpus. We rendered the corpus in accordance with the recommendations of Hannigan et al. (2019) by focusing on the coherence of the words within topics (see Table 1). In the hand-coding phase, we manually processed each paper to verify its conformity with the criteria of inclusion in our project (i.e., definition of adaptation and boundary conditions). We describe in Table 1 the three stages of our manuscript selection: sifting out, sifting in, and analysis.

Having identified 443 manuscripts in Stages 1 and 2 that conform to our criteria, in Stage 3 we identify topics from the final set of retained articles and hand-code each manuscript (conceptual or empirical) based on three primary characteristics: the definition of adaptation used in the manuscript, the measurement of adaptation, and the theoretical stream used in argumentation. The final model generated 16 topics classified under four themes to organize the literature. An online, interactive topic model displaying the clustering of topics and words can be found at https://sites.google.com/view/andrewsarta/research/interactive-topic-model. ${ }^{3}$ Figure 1 displays the results and Appendix B (see online supplement) provides details on the intermediate steps (e.g., keywords associated with each topic and their first-order coding). 


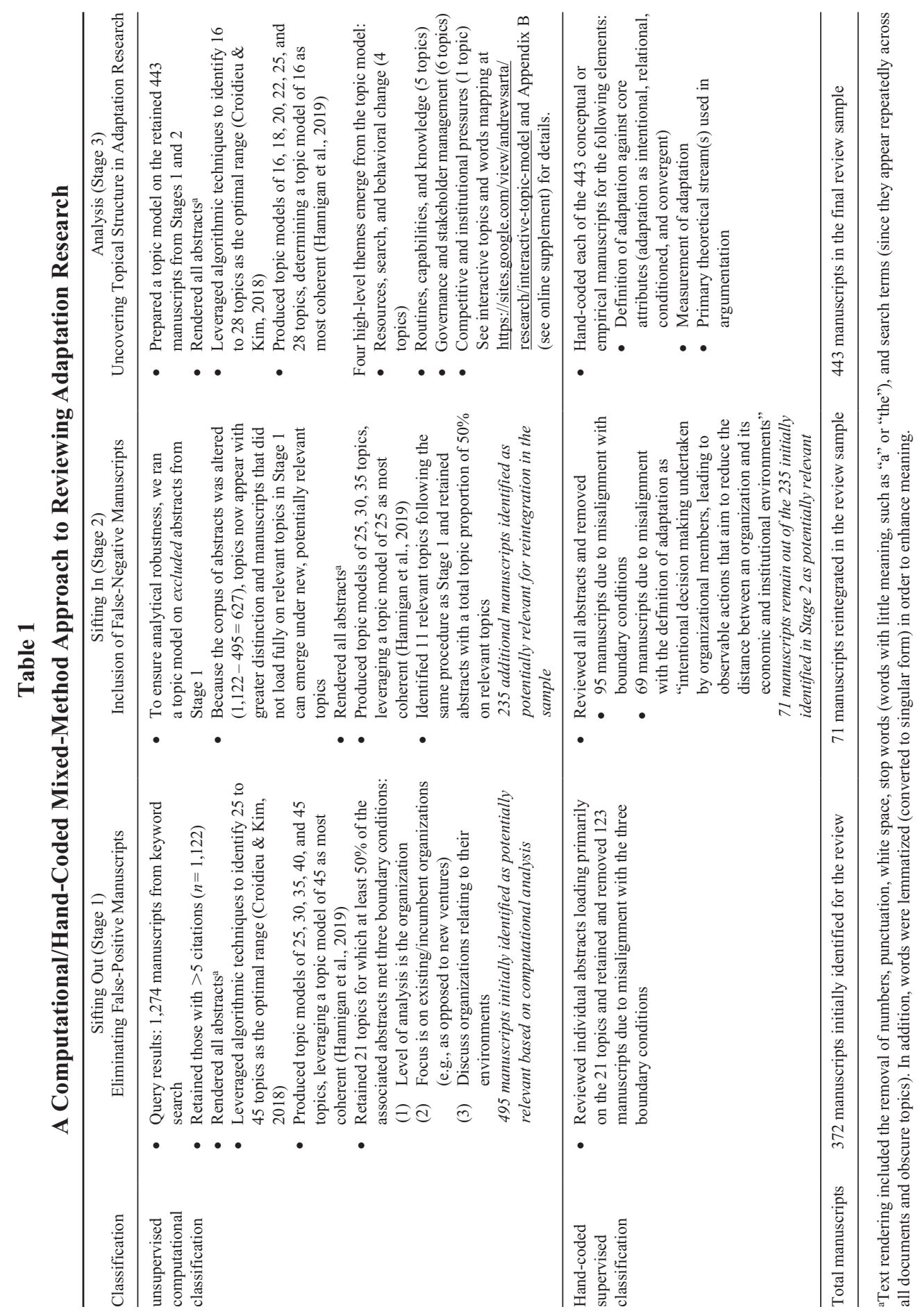


Figure 1

Themes Based on Intertopic Distance

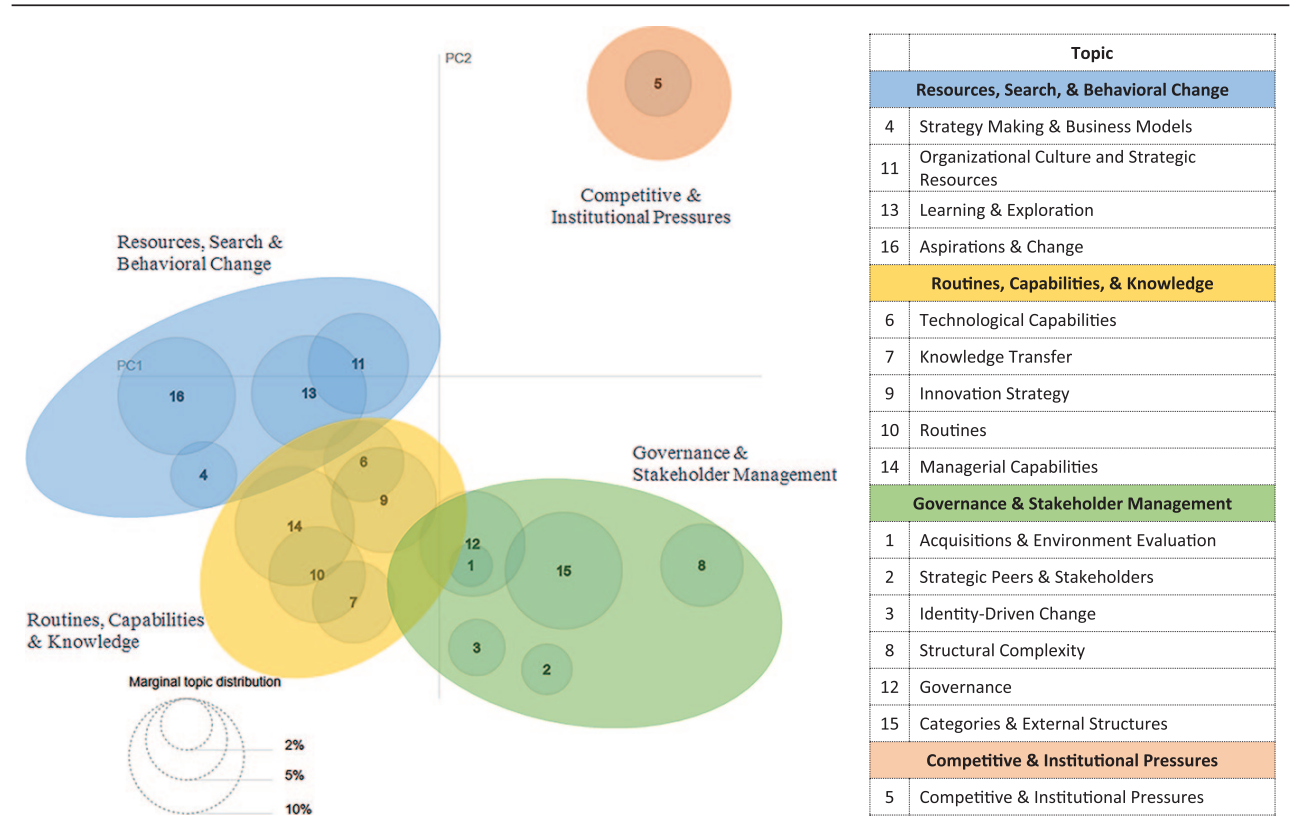

Note: Appendix B details the terms most associated with each topic as an output of the topic model (see online supplement). Ovals regroup topics in larger clusters based on intertopic distance. We colored and labeled groupings according to themes. Note that overlapping circles do not indicate an actual overlap in topics but result from the projection in a 2-dimension space of topics in an $n$-dimension space.

\section{Synthesizing the Adaptation Literature Around Three Areas of Inquiry}

Our hand-coding revealed the use of six theoretical streams across adaptation studies: behavioral theory, resource-based view (RBV), evolutionary economics, contingency perspectives, organizational sociology, and variation-selection-retention (VSR) models. ${ }^{4}$ Arranging the six streams and the four themes identified previously from the intra- to extraorganizational level delineates three areas of inquiry in adaptation scholarship: (a) why organizations pursue adaptation, (b) what internal factors preclude or enable adaptation, and (c) what environmental factors urge adaptation. Table 2 describes how the 443 papers map to each area of inquiry in a matrix with streams identified in rows and themes in columns.

\section{Thematic Review of the Three Areas of Inquiry in Adaptation Research}

To gain a complete picture of how adaptation has been studied, each of the three areas of inquiry identified in Table 2 is now reviewed from the perspective of each stream in terms of the main constructs invoked to explain adaptation, the theoretical mechanisms leveraged, 


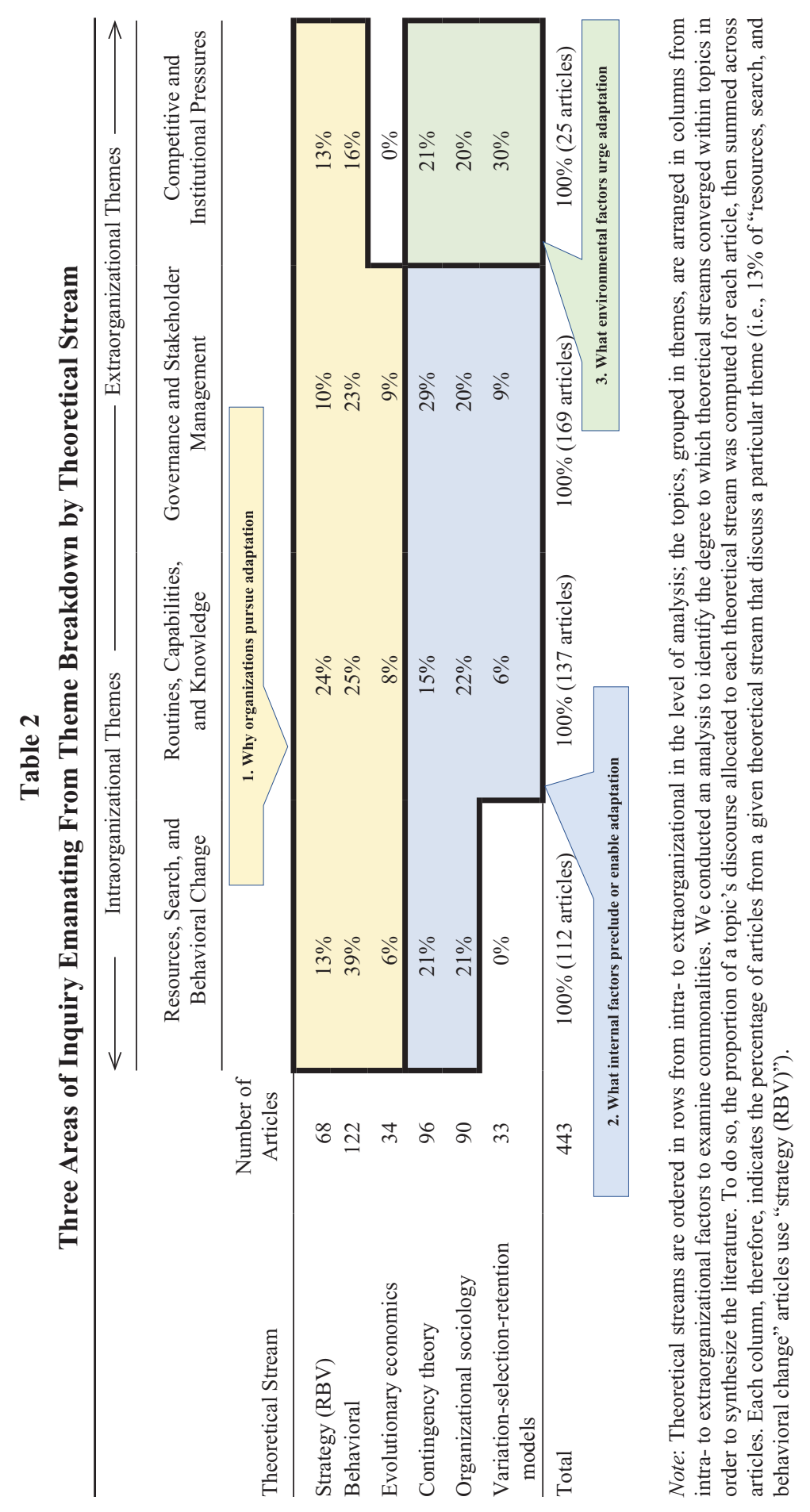


and the measures used to capture constructs and mechanisms. Table 3 provides a systematic review of adaptation research, alongside representative sets of published manuscripts.

As each area of inquiry is reviewed, potential theoretical and empirical difficulties that surface in adaptation research are flagged. Subsequently, the last section of our manuscript will go back to these difficulties in detail and provide ways to address them.

\section{Area of Inquiry (1/3): Why Organizations Pursue Adaptation}

The pursuit of adaptation is addressed with perspectives associated with the RBV, behavioral theory, and evolutionary economics. The main focus within this area of inquiry is on adaptation as a decision-making outcome, which emanates directly from the dominant theories leveraged (Cyert \& March, 1963; Nelson \& Winter, 1982).

Resources, search, and behavioral change as a theme often evokes organizations relating to their environments through the pursuit of new opportunities. In this respect, organizations as action generators (Starbuck, 1983) pursue adaptation by developing resources and capabilities through evolutionary processes (Ahuja \& Katila, 2004) or accumulated experiences that promote opportunity recognition and action (Eggers, 2012). Likewise, search initiatives are particularly important to pursuits of adaptation since they exhibit learning capabilities that produce stronger performance (Walter, Lechner, \& Kellermanns, 2016). Case in point, Ahuja and Katila (2004) illustrate how organizations develop innovative search processes that lead to resource creation by intentionally acting on situational triggers (technology exhaustion and international expansion).

In the behavioral stream, opportunity recognition implies a learning orientation based on balancing the "exploitation of old certainties" with the "exploration of new possibilities" (March, 1991: 71). In addition, cognitive schema direct managerial attention to particular aspects of the environment in order to spot innovative opportunities (Li, Maggitti, Smith, Tesluk, \& Katila, 2013). Evolutionary economics adds a modest element of constraint to this discussion by highlighting the internal challenges of overcoming past histories to find new opportunities (Denrell \& March, 2001). In this respect, Salvato and Rerup (2018) expose the regulatory actions that individuals mobilize within organizations to enact flexible routines when two conflicting goals constrain organizational adaptation.

Related research on routines, capabilities, and knowledge expands upon notions of opportunity recognition and focuses on the competitive benefits of adaptation through enhanced resource positions or improved strategic decisions. It is within this theme that strategy scholars elaborate upon the microfoundations of competitive advantage (Helfat \& Martin, 2015; Teece, 2007) and how cognitive capabilities allow organizations to move quickly into new markets to pursue new technologies. Eggers and Kaplan (2009) demonstrate that the focus of attention not only helps an incumbent organization to seize technological opportunities, but its interaction with organizational characteristics also determines the speed of entry in a novel sector. For them, "managerial cognition is a dynamic capability that can shape adaptation by established firms" (Eggers \& Kaplan, 2009: 461). Behavioral perspectives rely on the assumptions of bounded rationality and satisficing behavior in search of adaptation (Cyert \& March, 1963). Building on this tradition, subsequent research suggests that the careful management of communication channels that structure attention (Ocasio, 1997) and the ambidextrous structures that balance exploration and exploitation (Benner \& Tushman, 2002) can improve decision making and facilitate adaptation. Additionally, evolutionary theories 


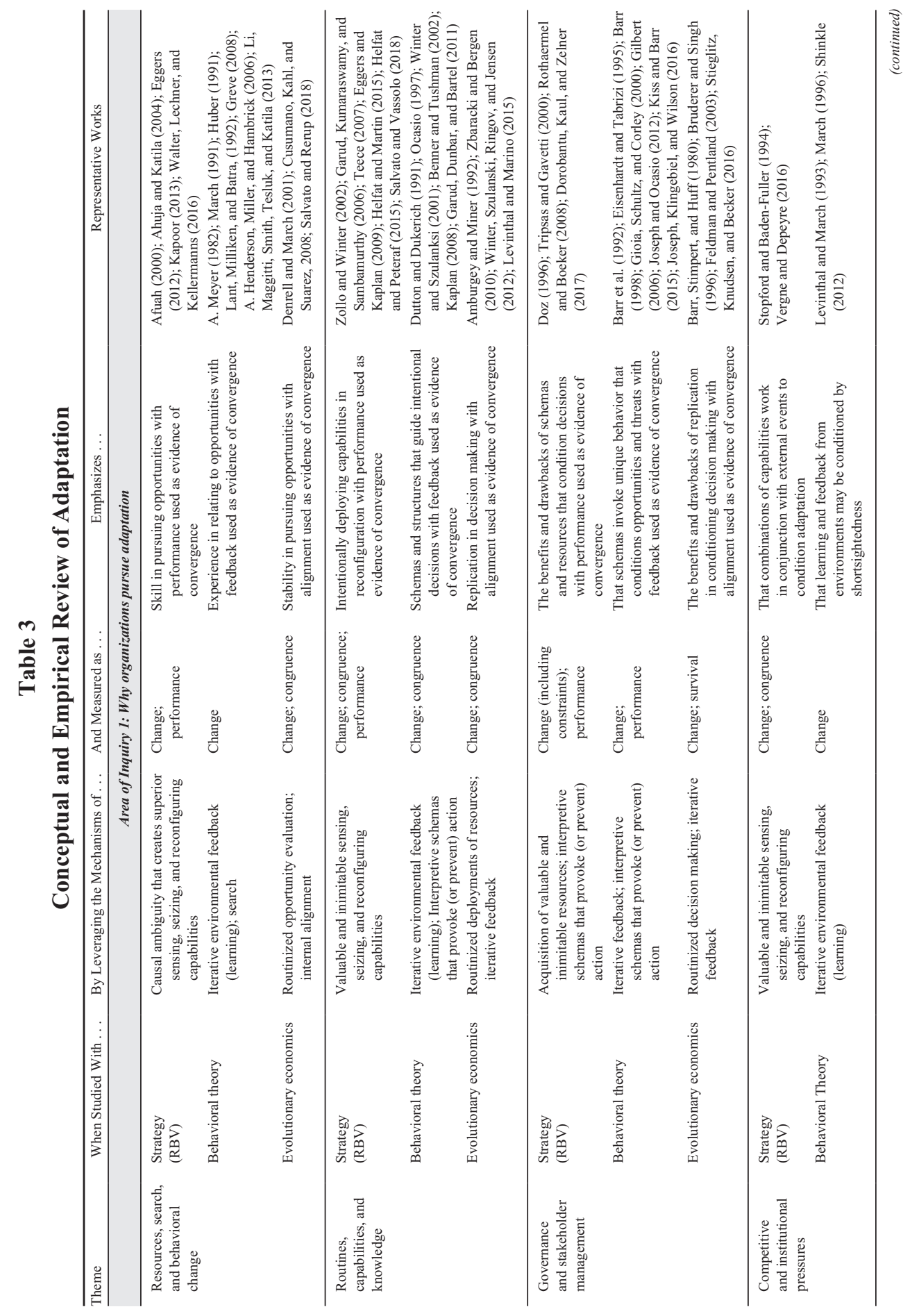




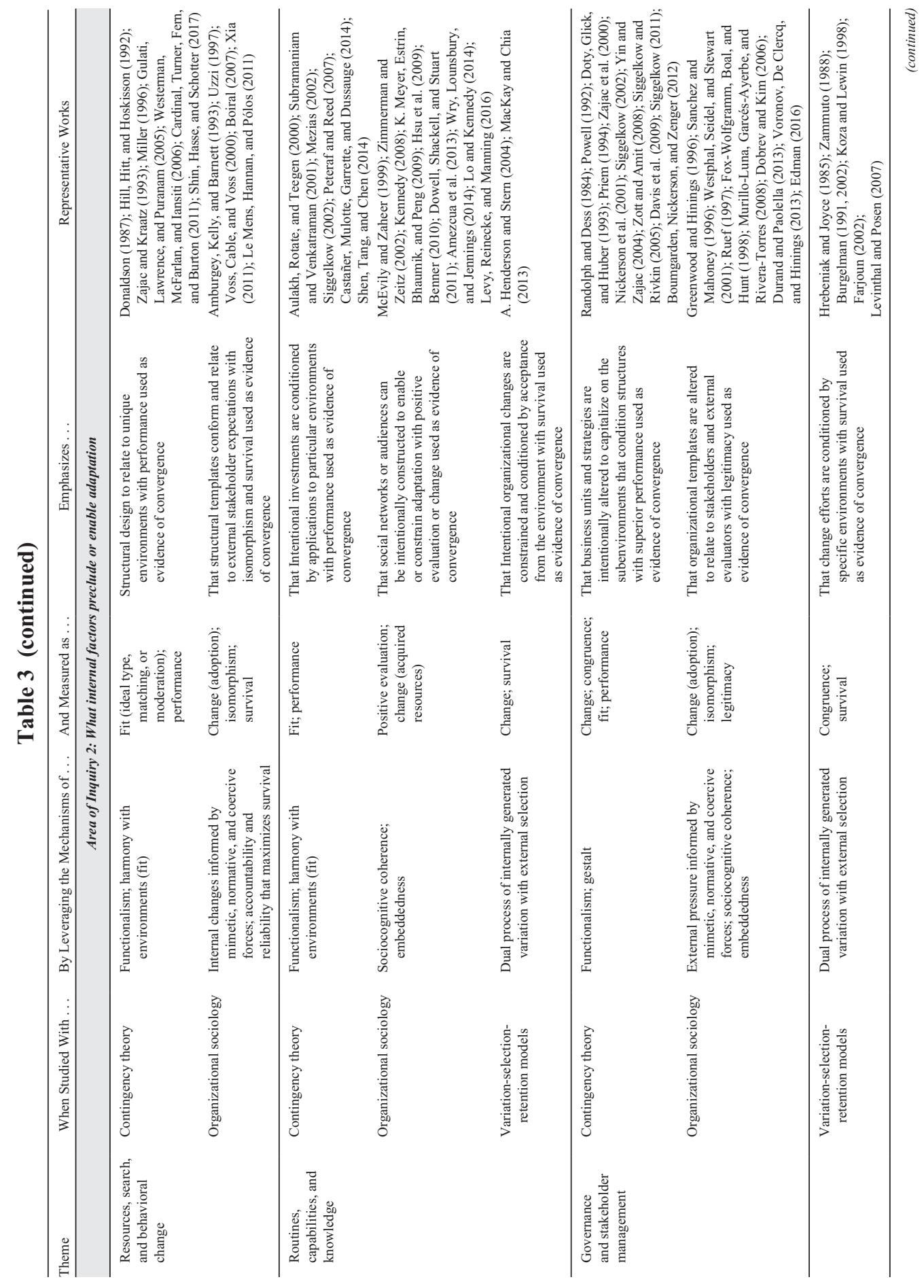




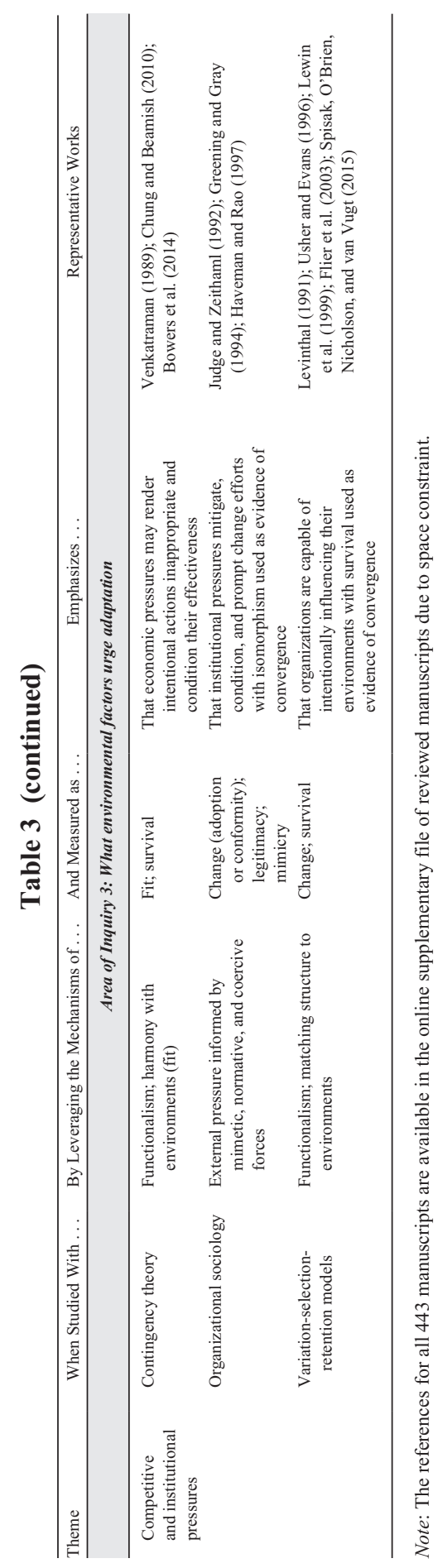


expand upon notions of overcoming internal routines to discuss how knowledge can be reproduced to translate an advantage from one setting to another (Amburgey \& Miner, 1992). In the franchisor-franchisee context, Winter, Szulanski, Ringov, and Jensen (2012) studied how a franchisee, by adjusting its routines to nonstandard products, increased its odds of failure, providing a counterintuitive example of a setting where strict routine replication provides a survival advantage, thus encouraging scholars to "revisit . . prevalent normative advice that favors ex ante adaptation" (p. 681).

Taken together, studies within these first two themes emphasize the intentional and relational aspects of adaptation but at times come accompanied with a view of organizations as having the agency to adapt to their environments without much resistance (which potentially presumes preordained effectiveness in decision making - raising a difficulty stemming from a "functionalist adaptation fallacy"). This hyperagentic view results in organizational convergence often being inferred through either the presence of strong performance (an assumption that performance equates to adaptation, raising a difficulty in accounting for "adaptation without strong performance") or the observation of consistent iterative adjustments (a difficulty being that routine, "continuous change" is not always indicative of adaptation).

As studies of the pursuit of adaptation move to higher levels of analysis, the emphasis shifts toward adaptation as conditioned by both internal and external factors. In studies under the theme governance and stakeholder management, constraints on the adaptation process emerge from boundedly rational actors that interpret their decision environments heterogeneously (Gavetti \& Levinthal, 2000). Along these lines, strategy scholars found that adaptation through strategic alliances is highly conditioned by initial successes (Doz, 1996) or that strong internal belief systems may crowd out the capabilities needed to pursue new technologies. Tripsas and Gavetti (2000) showed that Polaroid, despite possessing the knowledge and resources (e.g., patents on digital imaging), could neither innovate nor react to the digitization of the photo industry (note, however, that this kind of research on the antecedents of nonadaptation cannot generalize to explaining adaptation; pointing at a difficulty of "asymmetric causality"). Furthermore, whether or not organizations pursue new opportunities also depends on the ability to integrate managers' attention across hierarchies (Joseph \& Ocasio, 2012) and on the appropriate identification of environmental changes as opportunities or threats (Barr, Stimpert, \& Huff, 1992; Gilbert, 2006). Barr (1998), in a study of the pharmaceutical industry, shows that familiarity with an event shapes managerial interpretations and that strategic responses are "not undertaken until the stimuli is interpreted as having a direct impact on the performance or well-being of the organization" (p. 660). In this way, the agency of organizations becomes increasingly influenced by the (perceived) dynamics in the environment (raising a difficulty as "adaptation depends on environments").

In addressing why adaptation is pursued, the heavy emphasis on decision making and agency has pushed the examination of competitive and institutional pressures into the background. External triggers for change that induce varied responses are emphasized by strategy scholars. For example, in hostile financial environments subject to intense international competition, organizations that are triggered by extraorganizational factors but respond by incremental breaks with past behaviors were able to sustain superior performance (Stopford \& Baden-Fuller, 1994). Likewise, in Vergne and Depeyre (2016), configurations of cognition and capabilities conditioned adaptive responses of U.S. defense organizations responding to the $9 / 11$ attacks, but adaptation and performance, although positively correlated in their study (Pearson's $r=.53, p<.05$ ), form distinct constructs (with such distinction potentially 
circumventing the difficulty of "adaptation without strong performance"). Simultaneously, the authors identify that diversified defense organizations intentionally avoided adaptation toward military endeavors in favor of alternative lines of business, such as commercial information technology (the difficulty here being that organizations can engage in "strategic nonadaptation").

\section{Area of Inquiry (2/3): What Internal Factors Preclude or Enable Adaptation}

Whether adaptation is pursued relates to the strategic intent of organizations and their ability to change; however, streams most closely linked to organizational theory interpret adaptation differently, often with an emphasis on adaptation as an outcome. That's why the theoretical shift to contingency theory and organizational sociology conceptualizes adaptation as either performance (Lawrence \& Lorsch, 1967), legitimacy (J. Meyer \& Rowan, 1977), or survival (Hannan \& Freeman, 1977), with a corresponding focus on what organizations can modify internally to achieve these outcomes under constraints.

The theme of resources, search, and behavioral change approached from a contingency perspective emphasizes the search for the appropriate structural fit between an organization and its environment. For instance, Hill and colleagues (1992) use the concept of fit as a critical moderator explaining the classical relationship between (related and unrelated) diversification and financial performance. Contingency research underscores the functionality of fit and describes organizations as adapting their structures to gain and regain fit (Donaldson, 1987). As such, "regaining" fit emphasizes adaptation as both relational and conditioned in that alignment to environments produces stronger performance only under certain circumstances (Cardinal, Turner, Fern, \& Burton, 2011). In these cases, adaptation is implied by performance, again potentially conflating the two (difficulty: "adaptation without strong performance").

Sociologists specify how internal factors connect the organization with external demands. Neoinstitutionalists demonstrate that organizations seek conformance with stakeholder expectations (DiMaggio \& Powell, 1983), while network perspectives emphasize the role of embeddedness in social ties that both enables and constrains the flow of information (Uzzi, 1997). Resource dependence perspectives describe survival as an adaptive response that results from mutual dependence, which Xia (2011) outlines through a study of cross-border alliances that have greater survival odds when cross-border trading between countries is stronger. In contrast, while organizational ecologists initially downplayed the role of agency in favor of the accountability and reliability of organizational forms (Hannan \& Freeman, 1984), more recent studies suggest that organizations have some capacity to search and learn in order to reinforce survival odds (Le Mens, Hannan, \& Pólos, 2011), with survival itself serving as a proxy for convergence between organizations and their environment (Dobrev, Ozdemir, \& Teo, 2006). If survival can at times reflect adaptation, it can also reflect the absence or multiplicity of selection pressures that apply to organizations. In an integration of neoinstitutional and resource dependence perspectives, Durand and Jourdan (2012) highlight how organizations in the film industry adapt their behavior to minority players' demands in an effort to rebalance power relationships with dominant players (thereby revealing the difficulty that "adaptation depends on competition").

The theme of routines, capabilities, and knowledge emphasizes adaptation as intentional and conditioned, with a focus on the deployment of environment-specific organizational 
templates. For instance, contingency perspectives highlight the superior performance achieved when particular export strategies are deployed in suitable markets (Aulakh, Rotate, \& Teegen, 2000) or through appropriate uses of managerial discretion (Peteraf \& Reed, 2007). Siggelkow's (2002) in-depth case study of Vanguard exposes important processes around the organization's core competencies and their interdependencies, suggesting that an organization's ability to adapt may not be observable until opportunities present themselves (difficulty: "unobservable adaptive ability"). Organizational sociologists within this theme demonstrate the benefits of developing capabilities by maintaining social ties (McEvily \& Zaheer, 1999) or by deploying internationalization strategies to specific institutional contexts (K. Meyer, Estrin, Bhaumik, \& Peng, 2009). In addition, categorization scholars demonstrate that organizational templates and identities can be strategically targeted to various and specific audiences to impart value (Lo \& Kennedy, 2014; Paolella \& Durand, 2016; Wry, Lounsbury, \& Jennings, 2014). VSR models also depict organizations as agents of change in contexts where distinct selective environments pull organizations in contrarian directions (A. Henderson \& Stern, 2004). In these lines of work, performance, positive evaluations, and survival are used to indicate adaptation in response to demands emanating from multiple environments or audiences. Clearly, the assumption that organizations are adapting, at any given point in time, to one single environment is quite problematic (difficulty: "environmental multiplicity").

The theme of governance and stakeholder management further emphasizes the role of environments on adaptation. Contingency perspectives focus on enablers of adaptation by elaborating on the importance of deploying appropriate business models in specific environments (Zott \& Amit, 2008), theorizing on the importance of congruence between organizations and environments (Priem, 1994; Randolph \& Dess, 1984), and identifying the benefits of alignment for competitive advantage (Powell, 1992). Conversely, the institutional perspective, while predominantly focused on organizational fields, examines the ways in which organizations struggle to make internal changes and deal with mimetic, coercive, and normative isomorphic pressures (DiMaggio \& Powell, 1983). Examples are reflected in interactions between organizational identities and regulatory compliance that may constrain adaptation (Fiss \& Zajac, 2006; Fox-Wolfgramm, Boal, \& Hunt, 1998) and in mimicry for organizations seeking legitimacy when entering new markets (Haveman, 1993). Along this vein, neoinstitutionalists see adaptation as conditioned by the evaluations of stakeholders, with its convergent character coming from constrained choices to conform to institutional contexts (Greenwood \& Hinings, 1996). Murillo-Luna et al. (2008) specifically show that proactive organizational behavior is influenced by external pressures in the context of sustainability initiatives. Conformity and isomorphism, dictated by institutional logics, both underpin convergence toward organizational templates (Greenwood, Díaz, Li, \& Lorente, 2010), again indicating that some decisions (acts of conformity) reflect adaptation (difficulty: "functionalist adaptation fallacy"). VSR models emphasize convergence through homeostasis, where internal and external selection pressures regulate strategic change, which can ultimately manifest in coevolutionary lock-in, as Burgelman (2002) outlines in his study of Intel (difficulty stems from the likely presence of "coevolution across levels").

\section{Area of Inquiry (3/3): What Environmental Factors Urge Adaptation}

As external pressures compel organizations to adapt, the agentic perspectives prominent in accounts discussed previously fade and wane. Contingency theory, organizational sociology, 
and VSR models again feature prominently in this area of inquiry; however, the focus of attention shifts to accounts of the forces in the environment that kick-start the adaptation process.

Competitive and institutional pressures characterize environmental factors urging adaptation, with fit leveraged as a primary construct in contingency theories, albeit through multiple definitions. Venkatraman (1989) identified six distinct forms of fit: as mediation, moderation, matching, gestalt, deviance, and consistency. The inclusion of deviance in this list opens opportunities to analyze economic and institutional environments as potential rejecters of organizational change. Along the line of change being rejected, Chung and Beamish (2010) discuss the ineffectiveness of continuous ownership changes among international joint ventures, which produce instability and poor performance among partners.

For neoinstitutionalists, organizations have limited agency due to social norms and expectations. Haveman and Rao (1997) track the evolution of the early thrift industry through a study of entries, exits, and organizational form changes to demonstrate the interplay between selection forces in the technical environment and adaptation within institutional constraints. A key finding is that "over time, the effect of form change became beneficial" (Haveman \& Rao, 1997: 1633), thereby pointing to a difficulty in modeling "adaptation as transitory" and dynamic, as opposed to stable and discrete, in extant research. VSR models provide similar depictions, although in many cases strategic choice and environmental selection are seen as interrelated (Levinthal, 1991; Lewin \& Volberda, 1999). Such views suggest that as organizations change, they simultaneously influence the economic and institutional environments in which they reside, adding pressure to neighboring peer organizations (Durand, 2001; Lewin \& Volberda, 1999; Spisak, O’Brien, Nicholson, \& van Vugt, 2015) and bringing to bear the idea that organizations and environments influence one another (difficulty: "coevolution across levels").

\section{Overcoming Difficulties in Adaptation Research: A Path Forward}

As we systematically reviewed the literature, potential difficulties surfaced in association with specific theoretical frameworks, mechanisms, and construct measurements. Table 4, which expands on Vergne and Depeyre (2016), lists and describes each difficulty in general terms, and this section discusses potential approaches to addressing the difficulties. We thus move from reviewing the literature to integrating it based on consistent guidelines for scholars that can pave the way for a flourishing research agenda going forward. As depicted in the rows of Table 4, each grouping of difficulties is presented and subsequently followed by the tentative approaches to addressing the difficulty being analyzed.

To illustrate how our discussion applies to a real-world context, we introduce the example of open banking. Open banking has been described as "a secure and standardized technology which, when coupled with rules and procedures . . . allows consumers to safely create, share, or amend their digital records (e.g., transaction data, payment initiation, etc.) with authorized third-parties offering products and services" (Zachariadis, 2020: 8), including financial technology (fintech) startups that challenge incumbent banks' dominance. Regulation has mandated the transition to open banking in the United Kingdom and the European Union with similar frameworks being discussed in Canada, the United States, and Australia, providing an impetus for adaptation in nearly all of the world's largest banks (Zachariadis, Ozcan, \& Dinckol, 2018). Each difficulty will be brought to life with a brief example related to banks' adaptation amid the rise of open banking. 


\section{Difficulties Stemming From Conflation of Antecedents and Consequences}

The first set of difficulties associated with adaptation relates to the trouble in distinguishing adaptation from its antecedents and consequences. Adaptation is at times equated with change, congruence, strong performance, or survival (while strong performance and survival can be seen as consequences of change, hence the conflation). As a result, intended actions are often assumed to produce desired outcomes, and the meaning of convergence is often skewed to represent constructs not necessarily indicative of reduced distance between organizations and their environment(s). Three distinct difficulties are present in this grouping.

Functionalist adaptation fallacy. This difficulty stems from the presumption that organizational decisions work toward the proper functioning of the organization as a whole. Our review identifies such a presumption in the multiple streams that theorize organizational action as largely unrestricted or in the sociological stream that weighs heavily on what constrains actions. For instance, resource-based scholars predict that organizations possessing unique capabilities will be at a competitive advantage compared with their peers (Teece, 2007), although the literature does not clearly specify the conditions of either capability development or success (Vergne \& Durand, 2011). Empirically, in these cases, organizational adaptation is often described as symptomatic of organizations that are able to enact change through new product introduction (Salvato, 2009), risk taking in the executive suite (Rosenbloom, 2000), or special cognitive capabilities (Eggers \& Kaplan, 2009). The RBV, therefore, imported the tendency to measure adaptation as organizational change in a manner consistent with behavioral theory (Cohen \& Levinthal, 1990; Zahra \& George, 2002) while relating this change to competitive advantage - often measured as (strong) performance (Adner \& Helfat, 2003; Drnevich \& Kriauciunas, 2011; Powell, 2001; Rothaermel, 2001). In combination, clubbing these constructs together presumes the change made was appropriately "fit" or convergent with the environment due to the presence of capabilities, albeit with no validation that the change implemented was successful in reducing distance vis-à-vis the environment(s).

Take open banking in the United Kingdom, where the regulator forced the nine largest banks to adopt new standards in 2018-2019 in an effort to increase competition in the sector. Convergence with the institutional environment may be higher for these banks compared to smaller banks as a result, but it would be a mistake to infer either superior capabilities or competitive advantage from the early adoption of open banking (relative to smaller banks). Smaller banks that adapt to the rise of open banking later and more flexibly may well end up with a competitive advantage stemming from greater convergence with customer needs.

Adaptation without strong performance. The conceptual and logical association between fit (loosely understood as adaptation) and strong performance represents a weakness in extant research. Many studies are based on intuitive relationships that may not be as generalizable as one might believe at first. For instance, the claim that the greater the fit with one's environment, the greater the rent potential, has been debunked by the argument that rents, once created by an organization, may be appropriated by others (Coff, 1999). A few studies avoid this pitfall by specifying mechanisms, such as economies of scope that develop from structural alignment (Hill et al., 1992) or the coordination between buyers and suppliers that generate rent (Gulati, Lawrence, \& Puranam, 2005). Clarity is critical to 


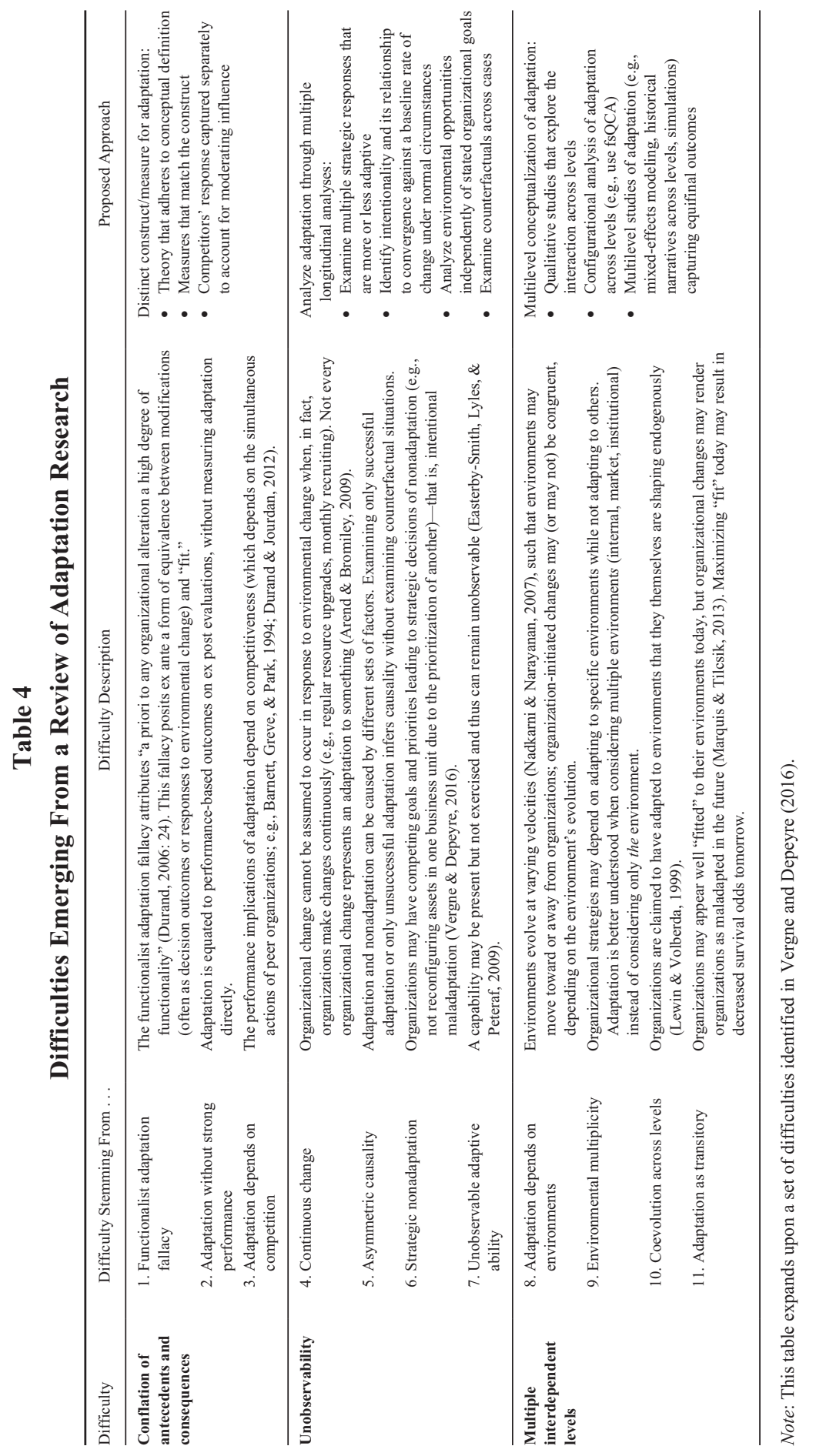


avoid conjectures that the performance or mere survival of an organization that underwent a change is indicative of "fit" or of being "well adapted." On this ground, Durand (2006: 110) warns that adaptation studied in this manner "is past-oriented and does not convey a causal determination of future odds of success."

In our example of open banking, incumbent banks are more likely to survive by adopting new technological standards (compliance is mandatory), but the increased competition that results from fintech start-ups' market entry may eventually erode performance. Such a scenario paints a picture whereby banks do adapt, most survive, but many might end up financially worse off.

Adaptation depends on competition. The fact that multiple organizations respond to one another suggests that adaptation is partly dependent on the actions of peer organizations and should not be assumed as independent (Pfeffer \& Salancik, 1978). For example, two organizations may independently pursue dominant designs (possibly resulting in population-level adaptation through technological adoption); however, only one will win (Rosenbloom \& Cusumano, 1987) as engaging in new standards increases selection pressure on all organizations participating (Durand, 2001). Scholars could be misled in believing that the adoption of initiatives (such as responding to institutional pressure or adopting new technology) reduces the distance between an organization and its environment(s) when such initiatives are considered independently of peers and broader conformity pressures. Conforming symbolically or partially to norms and regulations may, in fact, reflect poorly on organizations at the institutional level (Fiss \& Zajac, 2006; Greenwood et al., 2010). Jourdan, Durand, and Thornton (2017) describe and measure such a trade-off between social acceptance and financial performance - the latter can be reduced by efforts to defer and adjust to dominant social norms. Moreover, such contingencies have specific implications for the value of adaptation when considering adaptation and performance as distinct. For instance, many organizations adopting technology within close proximity to one another may be seen as "adapting" (in terms of meeting audience demands), but the performance benefits may depend on the interaction between organizations (R. Henderson \& Mitchell, 1997). Thus, the value captured from adaptation cannot be assumed as positive in itself and depends on what rivals do within their institutional and competitive environments.

Returning to open banking, the United Kingdom provides a context wherein large incumbents are simultaneously adopting similar technological standards and smaller banks can emulate their moves to various extents (Zachariadis \& Ozcan, 2017). Some organizations may haphazardly adopt the standards to the minimally acceptable requirements, while others may bullishly seek to benefit from open banking, creating a market where all banks are engaging in adaptation to different degrees, with each bank's outcomes being dependent on one another's actions. Some banks may even decide to exit particular market niches as part of their adaptation effort, thereby changing the benchmark used to assess relative performance among remaining competitors.

\section{Addressing Difficulties Stemming From Conflation of Antecedents and Consequences}

Our definition and review clearly distinguish adaptation as a specific type of strategic change that does not necessarily lead to superior performance but does imply convergence. 
Accordingly, and to overcome the difficulties discussed previously, scholars of adaptation should identify and capture the mechanisms that predict an intention to converge with a particular subenvironment (e.g., institutional, competitive) separately from the performance that results from strategic change.

By making this distinction, there would be potential to advance theory on adaptation from multiple angles by leveraging each theoretical stream's area of focus and strengths. At the intraorganizational level, behavioral theory often specifies strategic change as adaptation, while resource-based approaches specify performance as adaptation. Often, the mechanisms proposed in each stream do not adequately explain convergence as much as they explain change and performance, respectively. Leveraging research from both perspectives provides fertile ground for future research to examine the types of strategic change that induce convergence and the conditions under which convergence leads to superior performance. For example, the behavioral tradition identifies that threats induce earlier strategic responses (Barr, 1998) and that expedient decision-making may induce mistakes that create divergence rather than convergence (Perlow, Okhuysen, \& Repenning, 2002). Relatedly, resource-based perspectives suggest that early market entry indicates the presence of managerial capabilities that enhance performance (Adner \& Helfat, 2003; Eggers \& Kaplan, 2009). Yet the particular forms of expedient decision making that produce performance are underdeveloped. Theoretically distinguishing adaptation by emphasizing convergence allows for new mechanisms to be developed that establish a stronger causal chain from strategic change to adaptation and from adaptation to performance.

To implement our proposed approach at an empirical level, we suggest measuring adaptation as convergence or as a reduction in distance, using deviance scores (Deephouse, 1999; Nickerson \& Silverman, 2003; Powell, 1992), systematic bias in predicted values (Durand \& Kremp, 2016), Jaccard's similarity indices (Ruef, 1997), Dice coefficients (Smith, 2011), or survey-based measures (Vergne \& Depeyre, 2016), among others. Empirical strategies such as these will retain a conceptualization that distinguishes adaptation from strategic change, strong performance, competitive advantage, survival, and legitimacy. Additionally, measuring convergence directly removes the presumption of functionality in strategic change (since there is no assumed benefit to converging with a subenvironment) and accounts for dependent competitor actions (since a reduction in distance involves accounting for the relationship between a single organization and a broader population).

Interestingly, our proposed approach enables the theoretical possibilities that unintended consequences lead to convergence and that maladaptation procures higher returns than adaptation. While at first this may sound counterintuitive, the literature abounds with studies of radical innovators whose values, identities, and products clash with extant economic and social norms (Durand \& Vergne, 2013; Helms \& Patterson, 2014; Hiatt, Sine, \& Tolbert, 2009; Navis \& Glynn, 2010; Smith, 2011). That maladaptation (as divergence) can lead to extreme market differentiation and performance is also consistent with aspects of niche theory in ecological thinking (Hannan \& Freeman, 1989) and with arguments on superior performance deriving from uniqueness in resource-based theorizing (Barney, 1991).

\section{Difficulties Stemming From Unobservability}

A second set of difficulties that arise empirically are concerns in observing adaptation's presence in phenomena, manifesting in the following considerations for researchers. 
Continuous change. Organizations change continuously as they hire and promote employees, upgrade equipment and software, and routinely innovate to improve their products and services. Distinguishing between this baseline rate of change and strategic responses to identifiable market or institutional shifts is thus paramount to identifying adaptive changes. Moreover, since strong interdependencies exist within organizations, changing one characteristic (e.g., of an organization's strategy) may create momentum that triggers subsequent changes, resulting in interdependencies across time (Miller \& Friesen, 1980). Therefore, it is essential to consider the intentions and internal factors that condition organizational change when studying adaptation.

Relating the difficulty of continuous change to our real-world example, banks invest in new technology all the time, with investments peaking at pivotal moments, such as when the smartphone emerged in the late 2000s. The rise of open banking may be addressable by building on previous investments in (loosely related) technology; therefore, some banks may not need to adapt as much today because their historical baseline and existing momentum have placed them in a favorable position (intentionally or not).

Asymmetric causality. Asymmetric causality challenges the notion that adaptation and nonadaptation are explained by the same conditions (e.g., the presence or absence of a condition could play a moderate role in explaining adaptation but play no role at all in explaining nonadaptation). Studies that emphasize the inability to change (e.g., Tripsas \& Gavetti, 2000) at times identify as causal a condition (e.g., belief systems within Polaroid causing inertia) without examining counterfactual scenarios, thereby implying the benefits of strategic change when in fact we cannot know what the outcome would have been had the condition been absent or just different.

A global perspective on open banking brings asymmetric causality to life. Banks in the United Kingdom adapted to open banking faster than banks in the European Union; however, regulation forced the change to occur earlier. Without cross-country comparisons (i.e., counterfactuals), one cannot infer much about whether "faster" adaptation yields better organizational outcomes.

Strategic nonadaptation. Opposite to situations of intentional change is a scenario of intentional inertia that holds the potential to produce positive organizational outcomes. Empirically, this phenomenon of "strategic nonadaptation" (Vergne \& Depeyre, 2016) can occur when managers gauge that converging toward a shifting environment could hurt the organization's prospects (e.g., maybe divesting assets to refocus on more stable business segments is preferable). Strategic nonadaptation can be observed only when cross-level data sets document both top managerial awareness of environmental changes (at the organizational level) and value-creation opportunities (at the interface of the organization's resources and the multiple markets they can serve).

One of the larger value-creation opportunities with open banking is associated with the ability to have third parties initiate retail payments (Zachariadis, 2020). Banks with a weaker focus on payments, such as investment banks, may be less inclined to adapt in this context, and this approach need not penalize their performance or survival prospects. Such nonadaptation could be strategic.

Unobserved adaptive ability. In resource-based theories, adaptation tends to be implied by the deployment of capabilities that allow organizations to uniquely relate to their environ- 
ments versus less capable peers. Capabilities, however, are difficult to observe independently of their effect on the world. Three questions should be tackled by adaptation scholars to address this epistemological limitation: (a) Are organizations always aware of the capabilities they possess? (b) Can organizations have the appropriate capabilities but be unable to exercise them at the appropriate time? and (c) How do organizations update their capabilities as their environments change to alter the value of organizational assets? (Easterby-Smith, Lyles, \& Peteraf, 2009; Vergne \& Durand, 2011).

The case of open banking yields different opportunities for capability deployment in different markets. Take HSBC, one of the rare banks with retail operations in both the United Kingdom and Canada. HSBC has deployed open banking capabilities in the United Kingdom since it was part of the nine large incumbents initially picked by the regulator; however, in Canada, the absence of a regulatory framework for open banking (as of mid-2020) keeps HSBC's open-banking capabilities, as well as the learning experience amassed during their deployment in the United Kingdom, hidden from view.

\section{Addressing Difficulties Stemming From Unobservability}

Examining managerial intentions as they relate to environmental opportunities can shed new light on what was previously difficult to observe. For instance, understanding the interactions between an organization and multiple opportunities can reveal whether organizations aspire to achieve goals sequentially, as originally posited in A Behavioral Theory of the Firm (Cyert \& March, 1963), or simultaneously, whereby goals can conflict with one another (Gaba \& Greve, 2019). Revealing the behavior of organizations toward multiple opportunities can address the difficulties associated with continuous change and strategic nonadaptation since intentionality can be exposed to a greater extent. Empirically, archival data sources tracked over time provide vehicles through which intentionality can be identified contemporaneously for scholars of adaptation. For instance, the use of corporate documents (Eggers \& Kaplan, 2009; Joseph \& Ocasio, 2012) combined with the aforementioned measures of reduced distance can reveal relationships between the intentionality of decision makers and convergence to a greater degree.

Specifying the motives of decision makers brings clarity to adaptation; however, identifying counterfactuals should ideally accompany intentions in order to fully identify a change as adaptive. Solving for problems of asymmetric causality can be accomplished through the following methods that involve longitudinal data, provided they document both organizations and their environments to capture the relational nature of adaptation: panel analyses amenable to difference-in-difference estimation, instrumented models that capture the probability of intentional adaptive behavior in a first-stage equation (e.g., Jourdan et al., 2017), regression discontinuity designs, synthetic control methods, or multiple-case-study designs that can reveal complex and counterintuitive mechanisms of adaptation more explicitly (Martin \& Eisenhardt, 2010).

Finally, we would be remiss if we did not acknowledge that difficulties of unobservability can be addressed only partly with more controlled research designs. Within organizations, there is no such thing as DNA or genes that scholars can examine to link intrinsic characteristics to adaptation outcomes. This means that we should exercise caution as we infer theory from data and avoid making grand claims about near-magical (cap)abilities that some firms supposedly possess while others do not. 


\section{Difficulties Stemming From Interdependent Levels of Analysis}

Finally, the third set of difficulties emerges from the fact that three interdependent levels of analysis are present in the literature: the internal level, drawn from the resourcebased, behavioral, and contingency traditions; the market level, drawn from evolutionary economics and organizational ecology; and the institutional level, drawn primarily from neoinstitutionalism.

Adaptation depends on environments. Nothing precludes external environments from moving toward organizations, yet an assumption that environments are perpetually being chased by organizations underlies much of the literature on adaptation. Organizations are continually exploring and seeking feedback from environments (Levinthal, 1997; March, 1991) and scholars need to better specify the directions in which environments move. Major organizational change may not be necessary or appropriate in adaptive decision making depending upon the environmental dynamics. For instance, to adapt, organizations may simply need to unearth initiatives previously abandoned (Cattani, 2005). Characteristics of organizations and environments must be conjointly considered with specific attention to the environmental conditions that preclude or enable convergence.

Going back to our example, it is interesting to note that in Australia, open-banking standards landed much closer to incumbents' existing business models than they did in Europe (Zachariadis, 2020). Examining organizational adaptation through technology adoption alone may give an impression that European banks adapted to a greater extent when, in fact, Australian banks may converge with their new environmental conditions more so than European banks simply because Australian regulations landed closer to home.

Environmental multiplicity. Another concern emerging from our review is that each theoretical stream imposes a specific level of analysis - predominantly within organizations for behavioral and resource-based theories, and at the population or field level for organizational sociology - whereas adaptation, by definition, transcends boundaries between organizations and their environments (see Table 2). Therefore, considering one without the other makes the environment appear monolithic, implying that decision making deals with one environment at a time (e.g., market adaptation to the economic environment only). More realistically, though, organizations likely intend to adapt to multiple environments simultaneously, and each level of analysis conditions decision making (Burgelman, 1991; Levinthal, 1991; Zammuto, 1988).

Amid the rise of open banking, it would be a mistake to study adaptation from a technology standpoint alone (as part of market adaptation). As argued by Zachariadis (2020: 20),

In the UK, the origins of open banking were mostly grounded in the competition narrative [and this] was also the main reason Open Banking in the UK was "ordered" by the Competition and Markets Authority. . . . On the contrary, Australian regulators approached open banking from a data-rights perspective and regulated data-access through the Consumer Data Right bill.

Institutional factors shape the process heterogeneously across countries and have certainly influenced the buildup of organizations' internal resources and capabilities over time, creating disparities between domestic and global banks (with the latter exposed to multiple 
institutional histories). Any account of market adaptation in the context of open banking should thus consider internal and institutional adaptation as well to unpack how decision making leads to convergence across environments.

Coevolution across levels. Relatedly, particularly prominent, large, or influential organizations have the capacity to shape their environments, and the resulting coevolutionary processes need to be specified (Lewin \& Volberda, 1999). The absence of such an analysis may provide an illusion of adaptation when alternative constructs, including power dynamics (Casciaro \& Piskorski, 2005; Pfeffer \& Salancik, 1978), could adequately account for observed phenomena. Is it really adaptation that is taking place when the reduction in distance to the environment is entirely explained by an organization's influence on that environment? Presumably, no.

While in the United Kingdom the nine largest banks were forced to comply with many aspects of open-banking frameworks, in other countries it may be that powerful incumbents have enough clout to influence standard setting, thereby making adaptation more of an anticipatory game of environmental design than a reactive game of compliant adoption.

Adaptation as transitory. Not acknowledging the existence of coevolutionary processes can lead to a mistaken assumption of stability in adaptation, when in fact adaptation is transitory. For instance, internal structures may be designed to fit subenvironments in the short term, and a strong fit today may not persist tomorrow (Marquis \& Tilcsik, 2013). The notion of "residual fit," where capabilities retain alignment with portions of a changing environment (Gilbert, 2006), reinforces the view that if various environments change at different rates, then adaptation should be examined dynamically.

The swift adoption of open-banking technology by incumbent banks may provide shortterm benefits, but increased competition from fintech startups could further legitimize data sharing among consumers. In turn, this could erode incumbents' convergence with consumer needs in the long term as new services become available (e.g., possibly relying on a peer-topeer model).

\section{Addressing Difficulties Stemming From Interdependent Levels of Analysis}

Recognizing that adaptation operates at three distinct levels of analysis (internal, market, and institutional) and that these levels interact with each other are necessary first steps toward addressing this set of difficulties. Internal adaptation represents the degree to which organizations align their resources, competencies, structures, and goals (Baumann, Eggers, \& Stieglitz, 2019; Siggelkow, 2002); market adaptation represents the degree to which the organization's value proposition addresses its main audience's demands, such as customers for organizations or beneficiaries for nonprofit organizations (Helfat et al., 2009; Soule \& King, 2008); and institutional adaptation represents the alignment between organizations and the social norms in their institutional environments, which may manifest as conformity (DiMaggio \& Powell, 1983), mimicry (Haveman, 1993), or as the adoption-symbolic or not - of practices and templates (Greenwood et al., 2010; Jourdan et al., 2017). The multilevel characterization of adaptation clarifies the question of "to what is the organization adapting?" and facilitates the possibility that levels of analysis may condition one another (Baum \& Singh, 1994; Durand, 2006). 
In this line of thought, Levinthal's (1997) seminal piece, Adaptation on Rugged Landscapes, remains one of the most compelling attempts, to date, at modeling adaptation both across theoretical streams and levels of analysis with a consistent set of constructs. Levinthal integrates elements from organizational ecology (Hannan \& Freeman, 1977), contingency theory (Chandler, 1962), institutionalism (Stinchcombe, 1965), and the learning perspective (March \& Simon, 1958) to simulate the interaction between adaptation and selection forces. Such cross-fertilization produced valuable insights. First, the author suggests abandoning the problematic notion of fit and instead theorizes about "fitness," a function that maps deterministically a set of interdependent organizational attributes to a likelihood of survival. ${ }^{5}$ Second, since institutional histories constrain organizations to adapt locally by implementing incremental changes in their attributes, when attributes are highly interdependent ("tightly coupled"), several local optima surface that act as attractors for several organizational forms. By not equating adaptation with strong performance and by relating organizational changes to fitness implications across the internal, market, and institutional levels, Levinthal establishes the existence of multiple, equifinal paths leading to adaptation. ${ }^{6}$

Drawing on these insights, empirical researchers could rely on improved measurements of adaptation that capture convergence and leverage methods that can model equifinality using real-world data. Configurational approaches, after identifying adaptation through each of its four attributes and measuring convergence at each level of analysis, could offer interesting avenues for research. The variance in adaptation measures across levels of analysis could be exploited to generate new theoretical insights. Amid the rise of open banking, organizations may seek to increase institutional convergence by gaining legitimacy with government agencies (e.g., through lobbying), while others may pursue internal and market convergence with increased acquisitions and partnerships (e.g., to enhance capabilities and innovation speed). Configurational methodologies, such as fuzzy-set qualitative comparative analysis (fsQCA), are a welcome benefit in this context since unique measures of convergence can be simultaneously estimated across levels of analysis to identify "causal recipes" associated with an outcome of adaptation (Vergne \& Depeyre, 2016).

Through implementing research designs in this manner, we may well find that being well adapted at some level (e.g., institutional) is associated with average, not extraordinary, performance, as recent papers in the category stream of research might seem to indicate (Haans, 2019). Without a characterization of adaptation across levels of analysis, simplistic conceptions of adaptation will persist, and long-standing questions with respect to why some organizations adapt and thrive while others remain inert and fail will likely remain a challenge for adaptation scholars.

\section{Contributions}

First, we should stress the methodological originality of our literature review. The combination of computational models and hand-coding allowed three areas of inquiry to emerge from 443 manuscripts, which together cover six theoretical streams and tackle four broad themes. Arguably, the use of machine learning and natural-language processing on large bodies of text opens up new opportunities for large-scale reviews of cross-disciplinary literature. While machine-learning techniques have been used to synthesize text, our approach of coupling computational techniques with traditional hand-coding adds significant value to the 
review, ensuring that both breadth and depth are maintained. When combined, the dispersion of topics, grouped into themes, can be analyzed in conjunction with the theoretical assumptions leveraged in the articles. As a result, this method unravels the underlying logics connecting research streams, providing both opportunities for integration in addition to identifying sources of conceptual ambiguity (Hannigan et al., 2019; McMahan \& Evans, 2018). Our tables and analysis detail stepwise the mixed-method review process we implemented and can inspire other literature review writers in the future.

Second, our extensive review establishes a baseline definition of organizational adaptation that is inductively drawn from seminal works to identify four primary attributes of adaptation as being intentional, relational, conditioned, and convergent. Thus, we move beyond dictionary definitions to a conceptual definition that can ground scholars in future research. Confronting this definition with claims made in extant literature, we identify 11 difficulties likely to persist in the literature that can act as hurdles to overcome in future scholarship.

We review the difficulties identified and point at solutions to both guide researchers and open up new areas for future research in adaptation. By abandoning incorrect assumptions and by embracing new mechanisms and measures that capture the different attributes of adaptation, scholarship can progress and approach adaptation in its multiple dimensions (intentional, relational, conditioned, and convergent) while also recognizing its multilevel nature. We reasoned that investigating adaptation coherently at three levels (internal, market, and institutional) will both reveal subtle configurations of factors thus far obfuscated and deeply modify our knowledge — notably, that adaptation can be detrimental, that unintended fitness is not adaptation, or that maladaptation is not always lethal but can be advantageous.

Overall, we ponder whether, beyond contributing to each of the theoretical streams that elaborated partial aspects of our theorizing of adaptation, this review could hold the potential of surpassing each of them separately and give way to a new generation of research on organizational adaptation.

\section{ORCID iD}

Andrew Sarta iD https://orcid.org/0000-0002-0582-8523

\section{Notes}

1. Details on how we got to this definition are provided in the next section as well as in the appendix (see the online supplement). We thank an anonymous reviewer for pushing us to clarify the epistemological and nomological foundations of our definition.

2. The latter two journals were added to capture sociological perspectives that have been influential in organizational theory, and 1967 was chosen based on the publication year for Lawrence and Lorsch's (1967) seminal work.

3. A full reference list of the 443 manuscripts reviewed is available as an online supplementary file. Only studies cited in the main text are listed at the end of the manuscript due to space constraints.

4. Behavioral theory encompasses learning, aspirations, and cognition; resource-based theory includes work on dynamic capabilities and asset complementarities; evolutionary economics includes related literature elaborating on routines; contingency perspectives include literature on structural contingency theory, business models, and ideal-type organizational configurations; organizational sociology encompasses population ecology, neoinstitutionalism, categories, resource dependence, and network approaches; and variation-selection-retention models capture additional evolutionary models distinct from population ecology.

5. According to Levinthal (1997: 934), adaptation should be conceived of as "a change in a significant attribute of the organization ... [that] need not have a positive relationship to the probability of survival." 
6. On the downside, the study leaves managers with few actionable recommendations and offers no clear avenues for future empirical scholarship based on real-world data. Indeed, follow-up studies also rely on simulations to refine a model that, to our knowledge, has never been tested using real-world data (Levinthal \& Marino, 2015; Levinthal \& Posen, 2007).

\section{References}

Adner, R., \& Helfat, C. E. 2003. Corporate effects and dynamic managerial capabilities. Strategic Management Journal, 24: 1011-1025.

Afuah, A. 2000. How much do your coopetitors' capabilities matter in the face of technological change? Strategic Management Journal, 21: 397-404.

Ahuja, G., \& Katila, R. 2004. Where do resources come from? The role of idiosyncratic situations. Strategic Management Journal, 25: 887-907.

Aldrich, H. 1979. Organizations and environments. Stanford, CA: Stanford University Press.

Aldrich, H. E., \& Ruef, M. 2006. Organizations evolving. London: Sage.

Amburgey, T. L., Kelly, D., \& Barnett, W. P. 1993. Resetting the clock: The dynamics of organizational change and failure. Administrative Science Quarterly, 38: 51.

Amburgey, T. L., \& Miner, A. S. 1992. Strategic momentum: The effects of repetitive, positional, and contextual momentum on merger activity. Strategic Management Journal, 13: 335-348.

Amezcua, A. S., Grimes, M. G., Bradley, S. W., \& Wiklund, J. 2013. Organizational sponsorship and founding environments: A contingency view on the survival of business-incubated firms, 1994-2007. Academy of Management Journal, 56: 1628-1654.

Arend, R. J., \& Bromiley, P. 2009. Assessing the dynamic capabilities view: Spare change, everyone? Strategic Organization, 7: 75-90.

Aulakh, P. S., Rotate, M., \& Teegen, H. 2000. Export strategies and performance of firms from emerging economies: Evidence from Brazil, Chile, and Mexico. Academy of Management Journal, 43: 342-361.

Barnett, W. P., Greve, H. R., \& Park, D. Y. 1994. An evolutionary model of organizational performance. Strategic Management Journal, 15: 11-28.

Barney, J. 1991. Firm resources and sustained competitive advantage. Journal of Management, 17: 99-120.

Barr, P. S. 1998. Adapting to unfamiliar environmental events: A look at the evolution of interpretation and its role in strategic change. Organization Science, 9: 644-669.

Barr, P. S., Stimpert, J. L., \& Huff, A. S. 1992. Cognitive change, strategic action, and organizational renewal. Strategic Management Journal, 13(S1): 15-36.

Baum, J. A. C., \& Singh, J. V. 1994. Evolutionary dynamics of organizations. New York: Oxford University Press.

Baumann, O., Eggers, J. P., \& Stieglitz, N. 2019. Colleagues and competitors: How internal social comparisons shape organizational search and adaptation. Administrative Science Quarterly, 64: 275-309.

Benner, M. J. 2010. Securities analysts and incumbent response to radical technological change: Evidence from digital photography and internet telephony. Organization Science, 21: 42-62.

Benner, M. J., \& Tushman, M. 2002. Process management and technological innovation: A longitudinal study of the photography and paint industries. Administrative Science Quarterly, 47: 676.

Boiral, O. 2007. Corporate greening through ISO 14001: A rational myth? Organization Science, 18: 127-146.

Boumgarden, P., Nickerson, J., \& Zenger, T. R. 2012. Sailing into the wind: Exploring the relationships among ambidexterity, vacillation, and organizational performance. Strategic Management Journal, 33: 587-610.

Bowers, A. H., Greve, H. R., Mitsuhashi, H., \& Baum, J. A. C. 2014. Competitive parity, status disparity, and mutual forbearance: Securities analysts' competition for investor attention. Academy of Management Journal, 57: $38-62$.

Bruderer, E., \& Singh, J. V. 1996. Organizational evolution, learning, and selection: A genetic-algorithm-based model. Academy of Management Journal, 39: 1322-1349.

Burgelman, R. A. 1991. Intraorganizational ecology of strategy making and organizational adaptation: Theory and field research. Organization Science, 2: 239-262.

Burgelman, R. A. 2002. Strategy as vector and the inertia of coevolutionary lock-in. Administrative Science Quarterly, 47: 325-357. 
Cardinal, L. B., Turner, S. F., Fern, M. J., \& Burton, R. M. 2011. Organizing for product development across technological environments: Performance trade-offs and priorities. Organization Science, 22: 1000-1025.

Casciaro, T., \& Piskorski, M. J. 2005. Power imbalance, mutual dependence, and constraint absorption: A closer look at resource dependence theory. Administrative Science Quarterly, 50: 167-199.

Castañer, X., Mulotte, L., Garrette, B., \& Dussauge, P. 2014. Governance mode vs. governance fit: Performance implications of make-or-ally choices for product innovation in the worldwide aircraft industry, 1942-2000. Strategic Management Journal, 35: 1386-1397.

Cattani, G. 2005. Preadaptation, firm heterogeneity, and technological performance: A study on the evolution of fiber optics, 1970-1995. Organization Science, 16: 563-580.

Chakravarthy, B. S. 1982. Adaptation: A promising metaphor for strategic management. Academy of Management Review, 7: 35-44.

Chandler, A. D. 1962. Strategy and structure: Chapters in the history of the American enterprise. Cambridge, MA: MIT Press.

Chung, C. C., \& Beamish, P. W. 2010. The trap of continual ownership change in international equity joint ventures. Organization Science, 21: 995-1015.

Coff, R. W. 1999. When competitive advantage doesn't lead to performance: the resource-based view and stakeholder bargaining power. Organization Science, 10: 119-133.

Cohen, W. M., \& Levinthal, D. A. 1990. Absorptive capacity: A new perspective on learning and innovation. Administrative Science Quarterly, 35: 128.

Croidieu, G., \& Kim, P. H. 2018. Labor of love: Amateurs and lay-expertise legitimation in the early U.S. radio field. Administrative Science Quarterly, 63: 1-42.

Cusumano, M. A., Kahl, S. J., \& Suarez, F. F. 2008. Services, industry evolution, and the competitive strategies of product firms. Academy of Management Journal, 51: 315-334.

Cyert, R. M., \& March, J. G. 1963. A behavioral theory of the firm. Englewood Cliffs, NJ: Prentice-Hall.

Davis, J. P., Eisenhardt, K. M., \& Bingham, C. B. 2009. Optimal structure, market dynamism, and the strategy of simple rules. Administrative Science Quarterly, 54: 413-452.

Deephouse, D. L. 1999. To be different, or to be the same? it's a question (and theory) of strategic balance. Strategic Management Journal, 20: 147-166.

Denrell, J., \& March, J. G. 2001. Adaptation as information restriction: The hot stove effect. Organization Science, 12: 523-538.

DiMaggio, P. J., \& Powell, W. W. 1983. The iron cage revisited: Institutional isomorphism and collective rationality in organizational fields. American Sociological Review, 48: 147-160.

Dobrev, S. D., \& Kim, T.-Y. 2006. Positioning among organizations in a population: Moves between market segments and the evolution of industry structure. Administrative Science Quarterly, 51: 230-261.

Dobrev, S. D., Ozdemir, S. Z., \& Teo, A. C. 2006. The ecological interdependence of emergent and established organizational populations: Legitimacy transfer, violation by comparison, and unstable identities. Organization Science, 17: 577-597.

Donaldson, L. 1987. Strategy and structural adjustment to regain fit and performance: In defence of contingency theory. Journal of Management Studies, 24: 1-24.

Dorobantu, S., Kaul, A., \& Zelner, B. 2017. Nonmarket strategy research through the lens of new institutional economics: An integrative review and future directions. Strategic Management Journal, 38: 114-140.

Doty, D. H., Glick, W. H., \& Huber, G. P. 1993. Fit, equifinality, and organizational effectiveness: A test of two configurational theories. Academy of Management Journal, 36: 1196-1250.

Dowell, G. W. S., Shackell, M. B., \& Stuart, N. V. 2011. Boards, CEOs, and surviving a financial crisis: Evidence from the internet shakeout. Strategic Management Journal, 32: 1025-1045.

Doz, Y. L. 1996. The evolution of cooperation in strategic alliances: Initial conditions or learning processes? Strategic Management Journal, 17: 55-83.

Drnevich, P. L., \& Kriauciunas, A. P. 2011. Clarifying the conditions and limits of the contributions of ordinary and dynamic capabilities to relative firm performance. Strategic Management Journal, 32: 254-279.

Durand, R. 2001. Firm selection: An integrative perspective. Organization Studies, 22: 393-417.

Durand, R. 2006. Organizational evolution and strategic management. London: Sage.

Durand, R., \& Jourdan, J. 2012. Jules or Jim: Alternative conformity to minority logics. Academy of Management Journal, 55: 1295-1315.

Durand, R., \& Kremp, P.-A. 2016. Classical deviation: Organizational and individual status as antecedents of conformity. Academy of Management Journal, 59: 65-89. 
Durand, R., \& Paolella, L. 2013. Category stretching: Reorienting research on categories in strategy, entrepreneurship, and organization theory. Journal of Management Studies, 50: 1100-1123.

Durand, R., \& Vergne, J.-P. 2013. The pirate organization: Lessons from the fringes of capitalism. Cambridge, MA: Harvard Business Press.

Dutton, J. E., \& Dukerich, J. M. 1991. Keeping an eye on the mirror: Image and identity in organizational adaptation. Academy of Management Journal, 34: 517-554.

Easterby-Smith, M., Lyles, M. A., \& Peteraf, M. A. 2009. Dynamic capabilities: Current debates and future directions. British Journal of Management, 20(Suppl. 1): S1-S8.

Edman, J. 2016. Cultivating foreignness: How organizations maintain and leverage minority identities. Journal of Management Studies, 53: 55-88.

Eggers, J. P. 2012. All experience is not created equal: Learning, adapting, and focusing in product portfolio management. Strategic Management Journal, 33: 315-335.

Eggers, J. P., \& Kaplan, S. 2009. Cognition and renewal: Comparing CEO and organizational effects on incumbent adaptation to technical change. Organization Science, 20: 461-477.

Eggers, J. P., \& Park, K. F. 2018. Incumbent adaptation to technological change: The past, present, and future of research on heterogeneous incumbent response. Academy of Management Annals, 12: 357-389.

Eisenhardt, K. M., \& Tabrizi, B. N. 1995. Accelerating adaptive processes: Product innovation in the global computer industry. Administrative Science Quarterly, 40: 84-110.

Farjoun, M. 2002. Towards an organic perspective on strategy. Strategic Management Journal, 23: 561-594.

Fayol, H. 1916. General principles of management. Classics of Organization Theory, 2: 57-69.

Fayol, H. 1949. General and industrial management. New York: Pitman.

Feldman, M. S., \& Pentland, B. T. 2003. Reconceptualizing organizational routines as a source of flexibility and change. Administrative Science Quarterly, 48: 94.

Fiss, P. C., \& Zajac, E. J. 2006. The symbolic management of strategic change: Sensegiving via framing and decoupling. Academy of Management Journal, 49: 1173-1193.

Flier, B., Bosch, F. A. J. Van Den, \& Volberda, H. W. 2003. Co-evolution in strategic renewal behaviour of British, Dutch and French financial incumbents: Interaction of environmental selection, institutional effects and managerial intentionality. Journal of Management Studies, 40: 2163-2187.

Fox-Wolfgramm, S. J., Boal, K. B., \& Hunt, J. G. J. 1998. Organizational adaptation to institutional change: A comparative study of first-order change in prospector and defender banks. Administrative Science Quarterly, 43: 87.

Gaba, V., \& Greve, H. R. 2019. Safe or profitable? The pursuit of conflicting goals. Organization Science, 30: 647-667.

Garud, R., Dunbar, R. L. M., \& Bartel, C. A. 2011. Dealing with unusual experiences: A narrative perspective on organizational learning. Organization Science, 22: 587-601.

Garud, R., Kumaraswamy, A., \& Sambamurthy, V. 2006. Emergent by design: Performance and transformation at infosys technologies. Organization Science, 17: 277-286.

Gavetti, G., \& Levinthal, D. 2000. Looking forward and looking backward: Cognitive and experiential search. Administrative Science Quarterly, 45: 113.

Gilbert, C. G. 2006. Change in the presence of residual fit: Can competing frames coexist? Organization Science, 17: $150-167$.

Gioia, D. A., Schultz, M., \& Corley, K. G. 2000. Organizational identity, image, and adaptive instability. Academy of Management Review, 25: 63-81.

Greening, D. W., \& Gray, B. 1994. Testing a model of organizational response to social and political issues. Academy of Management Journal, 37: 467-498.

Greenwood, R., Díaz, A. M., Li, S. X., \& Lorente, J. C. 2010. The multiplicity of institutional logics and the heterogeneity of organizational responses. Organization Science, 21: 521-539.

Greenwood, R., \& Hinings, C. R. 1996. Understanding radical organizational change: Bringing together the old and the new institutionalism. Academy of Management Review, 21: 1022-1054.

Greve, H. R. 2008. A behavioral theory of firm growth: Sequential attention to size and performance goals. Academy of Management Journal, 51: 476-494.

Gulati, R., Lawrence, P. R., \& Puranam, P. 2005. Adaptation in vertical relationships: Beyond incentive conflict. Strategic Management Journal, 26: 415-440.

Haans, R. F. J. 2019. What's the value of being different when everyone is? The effects of distinctiveness on performance in homogeneous versus heterogeneous categories. Strategic Management Journal, 40: 3-27. 
Hannan, M. T., \& Freeman, J. 1977. The population ecology of organizations. American Journal of Sociology, 82: 929-964.

Hannan, M. T., \& Freeman, J. 1984. Structural inertia and organizational change. American Sociological Review, 49: $149-164$.

Hannan, M. T., \& Freeman, J. 1989. Organizational ecology. Cambridge, MA: Harvard University Press.

Hannigan, T., Haans, R. F. J., Vakili, K., Tchalian, H., Glaser, V., Wang, M., Kaplan, S., \& Jennings, P. D. 2019. Topic modeling in management research: Rendering new theory from textual data. Academy of Management Annals, 13: 586-632.

Haveman, H. A. 1993. Follow the leader: Mimetic isomorphism and entry into new markets. Administrative Science Quarterly, 38: 593-627.

Haveman, H. A., \& Rao, H. 1997. Structuring a theory of moral sentiments: Institutional and organizational coevolution in the early thrift industry. American Journal of Sociology, 102: 1606-1651.

Helfat, C. E., Finkelstein, S., Mitchell, W., Peteraf, M., Singh, H., Teece, D., \& Winter, S. G. 2009. Dynamic capabilities: Understanding strategic change in organizations. Oxford, UK: Wiley.

Helfat, C. E., \& Martin, J. A. 2015. Dynamic managerial capabilities: Review and assessment of managerial impact on strategic change. Journal of Management, 41: 1281-1312.

Helfat, C. E., \& Peteraf, M. A. 2015. Managerial cognitive capabilities and the microfoundations of dynamic capabilities. Strategic Management Journal, 36: 831-850.

Helms, W. S., \& Patterson, K. D. W. 2014. Eliciting acceptance for "illicit" organizations: The positive implications of stigma for MMA organizations. Academy of Management Journal, 57: 1453-1484.

Henderson, A. D., Miller, D., \& Hambrick, D. C. 2006. How quickly do CEOs become obsolete? Industry dynamism, CEO tenure, and company performance. Strategic Management Journal, 27: 447-460.

Henderson, A. D., \& Stern, I. 2004. Selection-based learning: The coevolution of internal and external selection in high-velocity environments. Administrative Science Quarterly, 49: 39-75.

Henderson, R. M., \& Mitchell, W. 1997. The interactions of organizational and competitive influences on strategy and performance. Strategic Management Journal, 18: 5-14.

Hiatt, S. R., Sine, W. D., \& Tolbert, P. S. 2009. From Pabst to Pepsi: The deinstitutionalization of social practices and the creation of entrepreneurial opportunities. Administrative Science Quarterly, 54: 635-667.

Hill, C. W. L., Hitt, M. A., \& Hoskisson, R. E. 1992. Cooperative versus competitive structures in related and unrelated diversified firms. Organization Science, 3: 501-521.

Hodgson, G. M. 2013. Understanding organizational evolution: Toward a research agenda using generalized darwinism. Organization Studies, 34: 973-992.

Hrebiniak, L. G., \& Joyce, W. F. 1985. Organizational adaptation: Strategic choice and environmental determinism. Administrative Science Quarterly, 30: 336-349.

Hsu, G., Hannan, M. T., \& Koçak, Ö. 2009. Multiple category memberships in markets: An integrative theory and two empirical tests. American Sociological Review, 74: 150-169.

Huber, G. P. 1991. Organizational learning: The contributing processes and the literatures. Organization Science, 2: $88-115$.

Joseph, J., Klingebiel, R., \& Wilson, A. J. 2016. Organizational structure and performance feedback: Centralization, aspirations, and termination decisions. Organization Science, 27: 1065-1083.

Joseph, J., \& Ocasio, W. 2012. Architecture, attention, and adaptation in the multibusiness firm: General Electric from 1951 to 2001. Strategic Management Journal, 33: 633-660.

Jourdan, J., Durand, R., \& Thornton, P. H. 2017. The price of admission: Organizational deference as strategic behavior. American Journal of Sociology, 123: 232-275.

Judge, W. Q., \& Zeithaml, C. P. 1992. Institutional and strategic choice perspectives on board involvement in the strategic decision process. Academy of Management Journal, 35: 766-794.

Kaplan, S. 2008. Framing contests: Strategy making under uncertainty. Organization Science, 19: 729-752.

Kapoor, R. 2013. Persistence of integration in the face of specialization: How firms navigated the winds of disintegration and shaped the architecture of the semiconductor industry. Organization Science, 24: 1195-1213.

Kennedy, M. T. 2008. Getting counted: Markets, media, and reality. American Sociological Review, 73: $270-295$.

Kiss, A. N., \& Barr, P. S. 2015. New venture strategic adaptation: The interplay of belief structures and industry context. Strategic Management Journal, 36: 1245-1263.

Koza, M. P., \& Lewin, A. Y. 1998. The co-evolution of strategic alliances. Organization Science, 9: 255-264. 
Lant, T. K., Milliken, F. J., \& Batra, B. 1992. The role of managerial learning and interpretation in strategic persistence and reorientation: an empirical exploration. Strategic Management Journal, 13: 585-608.

Lawrence, P. R., \& Lorsch, J. W. 1967. Differentiation and integration in complex organizations. Administrative Science Quarterly, 12: 1-47.

Le Mens, G., Hannan, M. T., \& Pólos, L. 2011. Founding conditions, learning, and organizational life chances: Age dependence revisited. Administrative Science Quarterly, 56: 95-126.

Levinthal, D. A. 1991. Organizational adaptation and environmental selection-interrelated processes of change. Organization Science, 2: 140-145.

Levinthal, D. A. 1997. Adaptation on rugged landscapes. Management Science, 43: 934-950.

Levinthal, D. A., \& March, J. G. 1993. The myopia of learning. Strategic Management Journal, 14(S2): 95-112.

Levinthal, D. A., \& Marino, A. 2015. Three facets of organizational adaptation: Selection, variety, and plasticity. Organization Science, 26: 743-755.

Levinthal, D., \& Posen, H. E. 2007. Myopia of selection: Does organizational adaptation limit the efficacy of population selection? Administrative Science Quarterly, 52: 586-620.

Levy, D., Reinecke, J., \& Manning, S. 2016. The political dynamics of sustainable coffee: Contested value regimes and the transformation of sustainability. Journal of Management Studies, 53: 364-401.

Lewin, A. Y., \& Volberda, H. W. 1999. Prolegomena on coevolution: A framework for research on strategy and new organizational forms. Organization Science, 10: 519-534.

Li, Q., Maggitti, P. G., Smith, K. G., Tesluk, P. E., \& Katila, R. 2013. Top management attention to innovation: The role of search selection and intensity in new product introductions. Academy of Management Journal, 56: 893-916.

Lo, J. Y.-C., \& Kennedy, M. T. 2014. Approval in nanotechnology patents: Micro and macro factors that affect reactions to category blending. Organization Science, 26: 119-139.

MacKay, R. B., \& Chia, R. 2013. Choice, chance, and unintended consequences in strategic change: A process understanding of the rise and fall of northco automotive. Academy of Management Journal, 56: 208-230.

March, J. G. 1991. Exploration and exploitation in organizational learning. Organization Science, 2: 71-87.

March, J. G. 1996. Continuity and change in theories of organizational action. Administrative Science Quarterly, 41: 278 .

March, J. G., \& Simon, H. A. 1958. Organizations. New York: Wiley.

Marquis, C., \& Tilcsik, A. 2013. Imprinting: Toward a multilevel theory. Academy of Management Annals, 7: 195245.

Martin, J. A., \& Eisenhardt, K. M. 2010. Rewiring: Cross-business-unit collaborations in multibusiness organizations. Academy of Management Journal, 53: 265-301.

McEvily, B., \& Zaheer, A. 1999. Bridging ties: A source of firm heterogeneity in competitive capabilities. Strategic Management Journal, 20: 1133-1156.

McKelvey, B. 1982. Organizational systematics: Taxonomy, evolution, classification. Berkeley: University of California Press.

McMahan, P., \& Evans, J. 2018. Ambiguity and engagement. American Journal of Sociology, 124: 860-912.

Merriam-Webster. n.d.. Adapt. Retrieved March 30, 2020, from https://www.merriam-webster.com/dictionary/ adapt

Meyer, A. D. 1982. Adapting to environmental jolts. Administrative Science Quarterly, 27: 515.

Meyer, J. W., \& Rowan, B. 1977. Institutionalized organizations: Formal structure as myth and ceremony. American Journal of Sociology, 83: 340-363.

Meyer, K. E., Estrin, S., Bhaumik, S. K., \& Peng, M. W. 2009. Institutions, resources, and entry strategies in emerging economies. Strategic Management Journal, 30: 61-80.

Mezias, J. M. 2002. Identifying liabilities of foreignness and strategies to minimize their effects: The case of labor lawsuit judgments in the United States. Strategic Management Journal, 23: 229-244.

Miles, R. E., Snow, C. C., Meyer, A. D., \& Coleman, H. J. 1978. Organizational strategy, structure, and process. Academy of Management Review, 3: 546.

Miller, D. 1996. Configurations revisited. Strategic Management Journal, 17: 505-512.

Miller, D., \& Friesen, P. H. 1980. Momentum and revolution in organizational adaptation. Academy of Management Journa1, 23: 591-614.

Murillo-Luna, J. L., Garcés-Ayerbe, C., \& Rivera-Torres, P. 2008. Why do patterns of environmental response differ? A stakeholders' pressure approach. Strategic Management Journal, 29: 1225-1240. 
Nadkarni, S., \& Narayanan, V. K. 2007. Strategic schemas, strategic flexibility, and firm performance: The moderating role of industry clockspeed. Strategic Management Journal, 28: 243-270.

Navis, C., \& Glynn, M. A. 2010. How new market categories emerge: Temporal dynamics of legitimacy, identity, and entrepreneurship in satellite radio, 1990-2005. Administrative Science Quarterly, 55: 439-471.

Nelson, R. R., \& Winter, S. G. 1982. An evolutionary theory of economic change. Cambridge, MA: Harvard University Press.

Nickerson, J. A., Hamilton, B. H., \& Wada, T. 2001. Market position, resource profile, and governance: Linking Porter and Williamson in the context of international courier and small package services in Japan. Strategic Management Journal, 22: 251-273.

Nickerson, J. A., \& Silverman, B. S. 2003. Why firms want to organize efficiently and what keeps them from doing so: Inappropriate governance, performance, and adaptation in a deregulated industry. Administrative Science Quarterly, 48: 433-465.

Ocasio, W. 1997. Towards an attention based view of the firm. Strategic Management Journal, 18(S1): 187-206.

Paolella, L., \& Durand, R. 2016. Category spanning, evaluation, and performance: Revised theory and test on the corporate law market. Academy of Management Journal, 59: 330-351.

Perlow, L. A., Okhuysen, G. A., \& Repenning, N. P. 2002. The speed trap: Exploring the relationship between decision making and temporal context. Academy of Management Journal, 45: 931-955.

Peteraf, M., \& Reed, R. 2007. Managerial discretion and internal alignment under regulatory constraints and change. Strategic Management Journal, 28: 1089-1112.

Pfeffer, J., \& Salancik, G. R. 1978. The external control of organisations (Vol. 175). New York: Harper and Row.

Podsakoff, P. M., MacKenzie, S. B., \& Podsakoff, N. P. 2016. Recommendations for creating better concept definitions in the organizational, behavioral, and social sciences. Organizational Research Methods, 19: 159-203.

Powell, T. C. 1992. Organizational alignment as competitive advantage. Strategic Management Journal, 13: 119134.

Powell, T. C. 2001. Competitive advantage: Logical and philosophical considerations. Strategic Management Journal, 22: 875-888.

Priem, R. L. 1994. Executive judgment, organizational congruence, and firm performance. Organization Science, 5: 421-437.

Randolph, W. A., \& Dess, G. G. 1984. The congruence perspective of organization design: A conceptual model and multivariate research approach. Academy of Management Review, 9: 114-127.

Rosenbloom, R. S. 2000. Leadership, capabilities, and technological change: The transformation of NCR in the electronic era. Strategic Management Journal, 21: 1083-1103.

Rosenbloom, R. S., \& Cusumano, M. A. 1987. Technological pioneering and competitive advantage: The birth of the VCR industry. California Management Review, 29: 51-76.

Rothaermel, F. T. 2001. Incumbent's advantage through exploiting complementary assets via interfirm cooperation. Strategic Management Journal, 22: 687-699.

Rothaermel, F. T., \& Boeker, W. 2008. Old technology meets new technology: Complementarities, similarities, and alliance formation. Strategic Management Journal, 29: 47-77.

Ruef, M. 1997. Assessing organizational fitness on a dynamic landscape: An empirical test of the relative inertia thesis. Strategic Management Journal, 18: 837-853.

Salvato, C. 2009. Capabilities unveiled: The role of ordinary activities in the evolution of product development processes. Organization Science, 20: 384-409.

Salvato, C., \& Rerup, C. 2018. Routine regulation: Balancing conflicting goals in organizational routines. Administrative Science Quarterly, 63: 170-209.

Salvato, C., \& Vassolo, R. 2018. The sources of dynamism in dynamic capabilities. Strategic Management Journal, 39: 1728-1752.

Sanchez, R., \& Mahoney, J. T. 1996. Modularity, flexibility, and knowledge management in product and organization design. Strategic Management Journal, 17: 63-76.

Shen, R., Tang, Y., \& Chen, G. 2014. When the role fits: How firm status differentials affect corporate takeovers. Strategic Management Journal, 35: 2012-2030.

Shin, D., Hasse, V. C., \& Schotter, A. P. J. 2017. Multinational enterprises within cultural space and place: Integrating cultural distance and tightness-looseness. Academy of Management Journal, 60: 904-921.

Shinkle, G. A. 2012. Organizational aspirations, reference points, and goals. Journal of Management, 38: 415-455.

Short, J. 2009. The art of writing a review article. Journal of Management, 35: 1312-1317. 
Siggelkow, N. 2002. Evolution toward fit. Administrative Science Quarterly, 47: 125-159.

Siggelkow, N. 2011. Firms as systems of interdependent choices. Journal of Management Studies, 48: 1126-1140. Siggelkow, N., \& Rivkin, J. W. 2005. Speed and search: Designing organizations for turbulence and complexity. Organization Science, 16: 101-122.

Smith, E. B. 2011. Identities as lenses: How organizational identity affects audiences' evaluation of organizational performance. Administrative Science Quarterly, 56: 61-94.

Soule, S. A., \& King, B. G. 2008. Competition and resource partitioning in three social movement industries. American Journal of Sociology, 113: 1568-1610.

Spisak, B. R., O’Brien, M. J., Nicholson, N., \& van Vugt, M. 2015. Niche construction and the evolution of leadership. Academy of Management Review, 40: 291-306.

Starbuck, W. H. 1971. Organizational growth and development. Middlesex, UK: Penguin.

Starbuck, W. H. 1983. Organizations as action generators. American Sociological Review, 48: 91.

Stieglitz, N., Knudsen, T., \& Becker, M. C. 2016. Adaptation and inertia in dynamic environments. Strategic Management Journal, 37: 1854-1864.

Stinchcombe, A. L. 1965. Social structure and organizations. In J. G. March (Ed.), Handbook of organizations, Vol. 7: 142-193. Chicago: Rand McNally.

Stopford, J. M., \& Baden-Fuller, C. W. F. 1994. Creating corporate entrepreneurship. Strategic Management Journal, 15: 521-536.

Subramaniam, M., \& Venkatraman, N. 2001. Determinants of transnational new product development capability: Testing the influence of transferring and deploying tacit overseas knowledge. Strategic Management Journal, 22: $359-378$.

Taylor, F. W. 1911. Principles and methods of scientific management. Journal of Accountancy, 12: 117-124.

Teece, D. J. 2007. Explicating dynamic capabilities: The nature and microfoundations of (sustainable) enterprise performance. Strategic Management Journal, 28: 1319-1350.

Tripsas, M., \& Gavetti, G. 2000. Capabilities, cognition, and inertia: Evidence from digital imaging. Strategic Management Journal, 21: 1147-1161.

Usher, J. M., \& Evans, M. G. 1996. Life and death along gasoline alley: Darwinian and Lamarckian processes in a differentiating population. Academy of Management Journal, 39: 1428-1466.

Uzzi, B. 1997. Social structure and competition in interfirm networks: The paradox of embeddedness. Administrative Science Quarterly, 42: 35.

Venkatraman, N. 1989. The concept of fit in strategy research: Toward verbal and statistical correspondence. Academy of Management Review, 14: 423-444.

Vergne, J.-P., \& Depeyre, C. 2016. How do firms adapt? A fuzzy-set analysis of the role of cognition and capabilities in U.S. defense firms responses to 9/11. Academy of Management Journal, 59: 1653-1680.

Vergne, J.-P., \& Durand, R. 2011. The path of most persistence: An evolutionary perspective on path dependence and dynamic capabilities. Organization Studies, 32: 365-382.

Voronov, M., De Clercq, D., \& Hinings, C. R. 2013. Conformity and distinctiveness in a global institutional framework: The legitimation of Ontario fine wine. Journal of Management Studies, 50: 607-645.

Voss, G. B., Cable, D. M., \& Voss, Z. G. 2000. Linking organizational values to relationships with external constituents: A study of nonprofit professional theatres. Organization Science, 11: 330-347.

Walter, J., Lechner, C., \& Kellermanns, F. W. 2016. Learning activities, exploration, and the performance of strategic initiatives. Journal of Management, 42: 769-802.

Westerman, G., McFarlan, F. W., \& Iansiti, M. 2006. Organization design and effectiveness over the innovation life cycle. Organization Science, 17: 230-238.

Westphal, J. D., Seidel, M. L., \& Stewart, K. J. 2001. Second-order imitation: Uncovering latent effects of board network ties. Administrative Science Quarterly, 46: 717.

Winter, S. G., \& Szulanski, G. 2001. Replication as strategy. Organization Science, 12: 730-743.

Winter, S. G., Szulanski, G., Ringov, D., \& Jensen, R. J. 2012. Reproducing knowledge: Inaccurate replication and failure in franchise organizations. Organization Science, 23: 672-685.

Wry, T., Lounsbury, M., \& Jennings, P. D. 2014. Hybrid vigor: Securing venture capital by spanning categories in nanotechnology. Academy of Management Journal, 57: 1309-1333.

Xia, J. 2011. Mutual dependence, partner substitutability, and repeated partnership: The survival of cross-border alliances. Strategic Management Journal, 32: 229-253.

Yin, X., \& Zajac, E. J. 2004. The strategy/governance structure fit relationship: Theory and evidence in franchising arrangements. Strategic Management Journal, 25: 365-383. 
Zachariadis, M. 2020. Data-sharing frameworks in financial services: Discussing open banking regulation for Canada. Report for Global Risk Institute, Toronto.

Zachariadis, M., \& Ozcan, P. 2017. The API economy and digital transformation in financial services: The case of open banking. Working paper no. 2016-001, SWIFT Institute, London.

Zachariadis, M., Ozcan, P., \& Dinckol, D. 2018. The economics and strategy of platforms: Competing in the era of open banking. In The book on open banking: A series of essays on the next evolution of money: 59-70. London: Bud Financial Limited.

Zahra, S. A., \& George, G. 2002. Absorptive capacity: A review, reconceptualization, and extension. Academy of Management Review, 27: 185-203.

Zajac, E. J., \& Kraatz, M. S. 1993. A diametric forces model of strategic change: Assessing the antecedents and consequences of restructuring in the higher education industry. Strategic Management Journal, 14: 83-102.

Zajac, E. J., Kraatz, M. S., \& Bresser, R. K. F. 2000. Modeling the dynamics of strategic fit: A normative approach to strategic change. Strategic Management Journal, 21: 429-453.

Zammuto, R. F. 1988. Organizational adaptation: Some implications of organizational ecology for strategic choice. Journal of Management Studies, 25: 105-120.

Zbaracki, M. J., \& Bergen, M. 2010. When truces collapse: A longitudinal study of price-adjustment routines. Organization Science, 21: 955-972.

Zimmerman, M. A., \& Zeitz, G. J. 2002. Beyond survival: Achieving new venture growth by building legitimacy. Academy of Management Review, 27: 414-431.

Zollo, M., \& Winter, S. G. 2002. Deliberate learning and the evolution of dynamic capabilities. Organization Science, 13: 339-351.

Zott, C., \& Amit, R. 2008. The fit between product market strategy and business model: Implications for firm performance. Strategic Management Journal, 29: 1-26. 